\title{
Sources and production of organic aerosol in Mexico City: insights from the combination of a chemical transport model (PMCAMx-2008) and measurements during MILAGRO
}

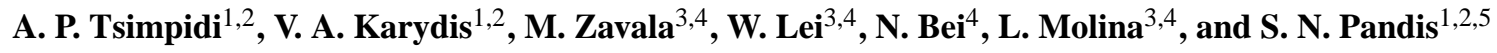 \\ ${ }^{1}$ Institute of Chemical Engineering and High Temperature Chemical Processes, Foundation for Research and Technology \\ Hellas, Patras, Greece \\ ${ }^{2}$ Dept. of Chemical Engineering, University of Patras, Patras, Greece \\ ${ }^{3}$ Department of Earth, Atmospheric and Planetary Sciences, Massachusetts Institute of Technology (MIT), USA \\ ${ }^{4}$ Molina Center for Energy and the Environment (MCE2), USA \\ ${ }^{5}$ Department of Chemical Engineering, Carnegie Mellon University, Pittsburgh, PA 15213, USA
}

Received: 15 October 2010 - Published in Atmos. Chem. Phys. Discuss.: 15 November 2010

Revised: 5 May 2011 - Accepted: 9 May 2011 - Published: 1 June 2011

\begin{abstract}
Urban areas are large sources of organic aerosols and their precursors. Nevertheless, the contributions of primary (POA) and secondary organic aerosol (SOA) to the observed particulate matter levels have been difficult to quantify. In this study the three-dimensional chemical transport model PMCAMx-2008 is used to investigate the temporal and geographic variability of organic aerosol in the Mexico City Metropolitan Area (MCMA) during the MILAGRO campaign that took place in the spring of 2006. The organic module of PMCAMx-2008 includes the recently developed volatility basis-set framework in which both primary and secondary organic components are assumed to be semivolatile and photochemically reactive and are distributed in logarithmically spaced volatility bins. The MCMA emission inventory is modified and the POA emissions are distributed by volatility based on dilution experiments. The model predictions are compared with observations from four different types of sites, an urban (T0), a suburban (T1), a rural (T2), and an elevated site in Pico de Tres Padres (PTP). The performance of the model in reproducing organic mass concentrations in these sites is encouraging. The average predicted $\mathrm{PM}_{1}$ organic aerosol (OA) concentration in $\mathrm{T} 0, \mathrm{~T} 1$, and $\mathrm{T} 2$ is $18 \mu \mathrm{g} \mathrm{m}^{-3}, 11.7 \mu \mathrm{g} \mathrm{m}^{-3}$, and $10.5 \mu \mathrm{g} \mathrm{m}^{-3}$ respectively, while the corresponding measured values are $17.2 \mu \mathrm{g} \mathrm{m}^{-3}, 11 \mathrm{~g} \mathrm{~m}^{-3}$, and $9 \mu \mathrm{g} \mathrm{m}^{-3}$. The average predicted locally-emitted primary OA concentrations,
\end{abstract}

Correspondence to: S. N. Pandis (spyros@chemeng.upatras.gr)
$4.4 \mu \mathrm{g} \mathrm{m}^{-3}$ at $\mathrm{T} 0,1.2 \mu \mathrm{g} \mathrm{m}^{-3}$ at $\mathrm{T} 1$ and $1.7 \mu \mathrm{g} \mathrm{m}^{-3}$ at PTP, are in reasonably good agreement with the corresponding PMF analysis estimates based on the Aerosol Mass Spectrometer (AMS) observations of $4.5,1.3$, and $2.9 \mu \mathrm{g} \mathrm{m}^{-3}$ respectively. The model reproduces reasonably well the average oxygenated OA (OOA) levels in T0 $\left(7.5 \mu \mathrm{g} \mathrm{m}^{-3}\right.$ predicted versus $7.5 \mu \mathrm{g} \mathrm{m}^{-3}$ measured), in $\mathrm{T} 1\left(6.3 \mu \mathrm{g} \mathrm{m}^{-3}\right.$ predicted versus $4.6 \mu \mathrm{g} \mathrm{m}^{-3}$ measured $)$ and in PTP $\left(6.6 \mu \mathrm{g} \mathrm{m}^{-3}\right.$ predicted versus $5.9 \mathrm{\mu g} \mathrm{m}^{-3}$ measured). The rest of the OA mass $\left(6.1 \mu \mathrm{g} \mathrm{m}^{-3}\right.$ and $4.2 \mu \mathrm{g} \mathrm{m}^{-3}$ in $\mathrm{T} 0$ and $\mathrm{T} 1$ respectively) is assumed to originate from biomass burning activities and is introduced to the model as part of the boundary conditions. Inside Mexico City (at T0), the locally-produced OA is predicted to be on average $60 \%$ locally-emitted primary (POA), $6 \%$ semi-volatile (S-SOA) and intermediate volatile (I-SOA) organic aerosol, and $34 \%$ traditional SOA from the oxidation of VOCs (V-SOA). The average contributions of the OA components to the locally-produced OA for the entire modelling domain are predicted to be $32 \% \mathrm{POA}, 10 \% \mathrm{~S}$ SOA and I-SOA, and $58 \% \mathrm{~V}-\mathrm{SOA}$. The long range transport from biomass burning activities and other sources in Mexico is predicted to contribute on average almost as much as the local sources during the MILAGRO period.

\section{Introduction}

The Mexico City Metropolitan Area (MCMA) is the largest megacity in North America and is one of the five largest cities in the world with over 20 million people living in an area of

Published by Copernicus Publications on behalf of the European Geosciences Union. 
$1500 \mathrm{~km}^{2}$. The MCMA has a history of severe air quality problems due to a large number of pollution sources with uneven levels of emission control, which can be further exacerbated by the topography and meteorology of the basin. The tropical location $\left(19^{\circ} \mathrm{N}\right)$ and high altitude $(2200 \mathrm{~m}$ above sea level) result in high UV radiation fluxes and intense photochemistry. The basin is surrounded by mountains on three sides, reducing ventilation of pollutants, especially at night and in the early morning (Molina and Molina, 2002).

Fine particulate matter (PM) is one of the most serious air quality problems in Mexico City (Molina et al., 2007). Pollution from megacities and large urban areas, such as MCMA, is important not only for its local effects on health (Pope and Dockery, 2006), visibility (Watson, 2002), and ecosystems/crops (Bytnerowicz and Fenn, 1996), but also because of its potential influence on regional scale atmospheric chemistry and radiative forcing. Organic species account for a large fraction of the fine aerosol mass at most locations (Zhang et al., 2007) and are poorly understood. The MILAGRO (Megacity Initiative: Local and Global Research Observations) field campaign, which took place during March 2006, used multiple sites and mobile platforms to assess pollutant emissions, and evolution in and around Mexico City (http://mce2.org/mcma2006), providing a unique dataset to study the formation of organic aerosols. The MILAGRO field experiment involved more than 400 researchers from over 120 institutions in the USA, Mexico, and several other countries (Molina et al., 2010). The campaign included coordinated aircraft and ground-based measurements supported by extensive modeling and satellite observations. Three main sites were chosen to characterize the transport and transformation of the pollutants carried from the urban area of the city to its surroundings; one in the urban area of Mexico City, designated as T0 and located in Northeast Mexico City at the Instituto Mexicano del Petroleo (IMP), and the other two, T1 and T2 were located, respectively at suburban and rural locations approximately $32 \mathrm{~km}$ and $63 \mathrm{~km}$ north of IMP respectively (Molina et al., 2010).

During MILAGRO daily average $\mathrm{PM}_{2.5}$ levels varied between $24-46 \mu \mathrm{g} \mathrm{m}^{-3}$ at the urban sites, $13-25 \mu \mathrm{g} \mathrm{m}^{-3}$ at the rural sites, and were around $30 \mu \mathrm{g} \mathrm{m}^{-3}$ at the industrial hotspot of Tula (Querol et al., 2008). Carbonaceous compounds accounted for a significant proportion of fine PM at the urban and industrial sites (around 50\%) and were markedly decreased at the suburban and rural sites (30\%) (Querol et al., 2008). DeCarlo et al. (2008) measured the concentration, size, and composition of non-refractory submicron aerosol (NR-PM1) over Mexico City and central Mexico with a High-Resolution Time-of-Flight Aerosol Mass Spectrometer (HR-ToF-AMS). OA correlated strongly with $\mathrm{CO}$ and $\mathrm{HCN}$ indicating that anthropogenic pollution and biomass burning (BB) were the main OA sources. Aiken et al. (2009) also used a HR-ToF-AMS to analyze submicron aerosols at the T0 urban site. The major components of OA were locally-emitted primary, biomass burning/woodsmoke and secondary sources at similar magnitudes. Yu et al. (2009) used the semi-empirical EC tracer method to derive primary organic carbon (POC) and secondary organic carbon (SOC) concentrations. The majority of organic carbon particles at $\mathrm{T} 1$ and $\mathrm{T} 2$ were secondary (an average of $63 \pm 17 \%$ and $67 \pm 12 \%$ respectively). The geographic distribution of photochemical age and $\mathrm{CO}$ was also examined by Kleinman et al. (2008), confirming that Mexico City is a major source region for the area and that pollutants become more dilute and aged as they are advected towards T1 and T2.

Stone et al. (2008) used a chemical mass balance (CMB) model based on molecular marker species in order to determine the relative contribution of major sources to ambient organic carbon (OC). Motor vehicles, including diesel and gasoline, consistently accounted for approximately $50 \%$ of $\mathrm{OC}$ in the urban area and $32 \%$ on the periphery. The daily contribution of $\mathrm{BB}$ to $\mathrm{OC}$ was highly variable, and ranged from $5-26 \%$ at the urban site and $7-39 \%$ at the peripheral site. The remaining OC unapportioned to primary sources showed a strong correlation with water soluble OC (WSOC) and was considered to be secondary in nature. Yokelson et al. (2007) also found high biomass burning emissions suggesting that the fires from forests near Mexico City could produce as much as $80-90 \%$ of the primary fine particle mass in the Mexico City area. The $50 \pm 30 \%$ of the "aged" fine particle mass in the March 2006 Mexico City outflow could be from these fires. Moreover, Crounse et al. (2009) found that fires contribute more than half of the organic aerosol mass and submicron aerosol scattering. DeCarlo et al. (2010) reported that during periods of high forest fire intensity near the basin, OA arising from open BB represents around $65 \%$ of the OA mass in the basin and contributes similarly to OA mass in the outflow. Aiken et al. (2010) estimated that during the low regional fire periods, $38 \%$ of OC in the Mexico City center was from non-fossil sources, suggesting the importance of urban and regional non-fossil carbon sources other than the fires, such as food cooking and regional biogenic SOA. They also showed that, by properly accounting for the non-BB sources of $\mathrm{K}$, the fires from the region near the MCMA are estimated to contribute 15-23\% of the OA. Finally, De Gouw et al. (2009) investigated the diurnal variations of hydrocarbons, elemental carbon (EC) and hydrocarbon-like organic aerosol (HOA) which were dominated by a high peak in the early morning. In comparison, diurnal variations of species with secondary sources such as OOA and WSOC stayed relatively high in the afternoon indicating strong photochemical formation.

Chemical transport models (CTMs) that can accurately and efficiently describe the physical and chemical atmospheric transformations of pollutants have been also used to estimate the chemical composition and the concentration of the aerosols in the MCMA (e.g., Karydis et al., 2010; Tsimpidi et al., 2010; Hodzic et al., 2009, 2010). Fast et al. (2009) assessed the uncertainties in predicted POA during MILAGRO before testing and evaluating the performance 
of secondary organic aerosol (SOA) treatments. Modeled POA was consistently lower than the measured OA at the ground sites, which is consistent with the expectation that SOA should be a large fraction of the total organic matter mass. Other studies have reported large discrepancies in the measured vs. modeled OOA mass concentrations in both urban and regional polluted atmospheres (Heald et al., 2005; de Gouw et al., 2005; Johnson et al., 2006; Volkamer et al., 2006; Kleinman et al., 2008). Hodzic et al. (2009) found fairly good agreement between predicted and observed POA within the city but large discrepancies were encountered for SOA, suggesting that less than $15 \%$ of the observed SOA within the Mexico City can be explained by the oxidation of the traditional SOA precursors. These results are in agreement with the findings of Dzepina et al. (2009) where the traditional SOA precursors (mainly aromatics) by themselves failed to produce enough SOA to match the observations by a factor of 7. Hodzic et al. (2010) applied the CHIMERE model to estimate the potential contribution to SOA formation of recently identified semi-volatile and intermediate volatility organic precursors (Robinson et al., 2007) in and around Mexico City. Their results showed a substantial enhancement in predicted SOA concentrations (2-4 times) both within and downwind of the city leading to much reduced discrepancies with the total OA measurements.

Robinson et al. (2007) proposed two major amendments to the current treatment of OA: (1) accounting for the volatility and gas particle partitioning of POA; and (2) explicit representation of gas-phase oxidation of all low-volatility vapors in SOA production mechanisms. These amendments were implemented in a 3D-CTM, PMCAMx, resulting in the PMCAMx-2008 version (Lane et al., 2008a, b; Shrivastava et al., 2008; Murphy and Pandis, 2009). Tsimpidi et al. (2010) applied PMCAMx-2008 in MCMA during the MCMA-2003 campaign (Molina et al., 2007), reducing significantly the discrepancies between the measured and the modeled OOA. However, that study was limited by the availability of organic aerosol measurements in only one site.

The current study is based on the insights of the work of Tsimpidi et al. (2010) and its goal is to assess further the temporal and geographic variability of organic mass compounds during the 2006 MILAGRO campaign using PMCAMx2008. The geographic variability of the OA concentration is evaluated by comparing the model predictions against measurements taken at an urban site in Mexico City, two peripheral sites located on the outskirts of the metropolitan area, and an elevated site located at Pico de Tres Padres (PTP). This study aims to improve our understanding of the formation pathways of organic aerosol in Mexico City.

\section{Model description}

PMCAMx-2008 simulates advection, dispersion, gas-phase chemistry, emission, wet/dry deposition, aerosol dynamics and aqueous-phase chemistry of atmospheric compounds (Gaydos et al., 2007; Karydis et al., 2007). Following Tsimpidi et al. (2010), a volatility distribution is applied to the emitted POA species with nine simulated volatility bins, ranging from $10^{-2}$ to $10^{6} \mu \mathrm{g} \mathrm{m} \mathrm{m}^{-3}$ saturation concentration (all effective saturation concentrations in the VBS are at $298 \mathrm{~K}$ and $1 \mathrm{~atm}$ ). This simulation also includes emissions of intermediate volatility organic compounds (IVOCs), which are distributed among the $10^{3}, 10^{4}, 10^{5}$, and $10^{6} \mu \mathrm{g} \mathrm{m}^{-3}$ saturation concentration bins with emissions rates equal to 0.3 , $0.4,0.5$, and 0.8 times the original non-volatile POA emission rate, respectively. The gas-phase chemical mechanism in use is based on SAPRC-99, that includes 56 gas-phase species (not including the gas- and particulate-phase organic species added for this study), 18 free radicals, and 211 reactions (Carter, 2000). This mechanism is updated to include gas-phase oxidation of S-SOA and I-SOA and V-SOA precursors. The number of species and reactions may vary from application to application (i.e. Farina et al., 2010; Shrivastava et al., 2010) depending on the desired chemical resolution (number of size and volatility bins). SOA is split between aerosol formed from the condensation of the oxidation products of the volatile organic compounds (V-SOA), intermediate volatile organic compounds (I-SOA), and semivolatile organic compounds (S-SOA). The V-SOA is simulated with 4 volatility bins $\left(1,10,100,1000 \mu \mathrm{g} \mathrm{m}^{-3}\right)$, and 10 size bins (diameters range from 0.04 to $40 \mu \mathrm{m}$ ). I-SOA and S-SOA are described with 9 volatility bins $\left(10^{-2}-\right.$ $10^{6} \mathrm{\mu g} \mathrm{m}^{-3}$ ) and 10 size bins. The V-SOA yields used in PMCAMx-2008 are based on the $\mathrm{NO}_{\mathrm{x}}$-dependent stoichiometric yields of Lane et al. (2008b). However, following Murphy and Pandis (2009) and Tsimpidi et al. (2010), the anthropogenic yields for the low- $\mathrm{NO}_{\mathrm{x}}$ case correspond to the high-yield case investigated by Lane et al. (2008b). Recent laboratory studies ( $\mathrm{Ng}$ et al., 2006; Hildebrandt et al., 2009) have indicated that these higher yields are more accurate so the yields used in this work have been calculated by multiplying the experimentally determined volume concentrations by a density of $1.5 \mathrm{~g} \mathrm{~cm}^{-3}$ (Kostenidou et al., 2007). The corresponding parameters affecting V-SOA, ISOA, and S-SOA partitioning and removal processes, including effective Henry's law constants, molecular weights and enthalpies of vaporization, are taken from Tsimpidi et al. (2010). Further gas-phase oxidation of SOA vapors (chemical aging) is modeled using a second-order reaction with hydroxyl radicals. To express the decrease of volatility with aging, products of this reaction are shifted down one volatility bin (factor of 10 reduction in effective saturation concentration). The base-case simulation ages S-SOA, I-SOA and V-SOA from anthropogenic sources using a rate constant $k(298 \mathrm{~K})=40 \times 10^{-12} \mathrm{~cm}^{3} \mathrm{molec}^{-1} \mathrm{~s}^{-1}$ for S-SOA and I-SOA and $k(298 \mathrm{~K})=10 \times 10^{-12} \mathrm{~cm}^{3} \mathrm{molec}^{-1} \mathrm{~s}^{-1}$ for V-SOA. No biogenic SOA aging is simulated based on both the available laboratory studies ( $\mathrm{Ng}$ et al., 2006; Presto et al., 2006) and the results of Lane et al. (2008a). Overall, 




Fig. 1. The modeling domain for the Mexico City Metropolitan Area during the MILAGRO campaign. Also shown, the locations of the monitoring stations during the campaign.

the model, apart from the locally-emitted primary organic aerosols (POA), simulates three types of oxygenated organic aerosols based on the initial volatility of the corresponding precursor compounds: S-SOA $\left(\mathrm{C}^{*} \leq 10^{2} \mu \mathrm{g} \mathrm{m}^{-3}\right)$, I-SOA $\left(10^{3} \leq \mathrm{C}^{*} \leq 10^{6} \mu \mathrm{g} \mathrm{m}^{-3}\right)$, and V-SOA $\left(\mathrm{C}^{*}>10^{6} \mu \mathrm{g} \mathrm{m}^{-3}\right)$. A more comprehensive description of the organic aerosol module used by PMCAMx-2008 can be found in Tsimpidi et al. (2010), Murphy and Pandis (2009), Lane et al. (2008a, b), and Shrivastava et al. (2008).

\section{Model application}

This study uses PMCAMx-2008 to simulate March 2006 for the Mexico City Metropolitan Area. The first three days of the simulation are used for initialization and are not included in the results presented here. The modeling domain covers a $210 \times 210 \mathrm{~km}$ region in the Mexico City Metropolitan Area with $3 \times 3 \mathrm{~km}$ grid resolution and fifteen vertical layers totaling $6 \mathrm{~km}$ (Fig. 1). This is a much larger domain than that used by Tsimpidi et al. (2010) and includes the industrial area of Tula to the north of Mexico City (Song et al., 2010). Inputs to the model include horizontal wind components, temperature, pressure, water vapor, vertical diffusivity, clouds, and rainfall; all created using the Weather Research and Forecast (WRF) model.
Table 1. Organic compound emission rates (tons $\mathrm{d}^{-1}$ ) over the modeling domain.

\begin{tabular}{lr}
\hline Organic compound & Emission rate (tons d ${ }^{-1}$ ) \\
\hline Anthropogenic VOCs & 2572 \\
Biogenic VOCs & 954 \\
Intermediate volatile compounds & 217 \\
Semi-volatile compounds & 55 \\
\hline
\end{tabular}

\subsection{Emission inventory}

The emission inventory has been updated in order to include the anthropogenic emissions from the refinery, power plant and chemical companies in the Tula area located north of Mexico City (Fig. 1), the biogenic emissions from the forests located on the northeast part of the model domain, and a semi-empirical HONO "source" $\left(0.8 \%\right.$ of the $\mathrm{NO}_{\mathrm{x}}$ emissions based on Aumont et al. (2003) and Li et al. (2010)). In order to account for partitioning of primary organic emissions, the emission inventory was modified following the recommendations of Tsimpidi et al. (2010). Table 1 shows the amount of the emitted organic material within the limits of the modeling domain. Anthropogenic and biogenic VOC emissions serve as anthropogenic and biogenic V-SOA precursors respectively. Semivolatile (SVOC; $10^{-2} \leq \mathrm{C}^{*} \leq 10^{2} \mu \mathrm{g} \mathrm{m}^{-3}$ ) primary organic emissions partition between the aerosol and the gas phase. The material that remains in the aerosol phase is locally-emitted POA while the gas phase material, which is subsequently oxidized by $\mathrm{OH}$, is considered as S-SOA precursor. Intermediate-volatility (IVOC; $10^{3} \mu \mathrm{g} \mathrm{m}^{-3} \leq \mathrm{C}^{*} \leq$ $10^{6} \mathrm{\mu g} \mathrm{m}^{-3}$ ) organic compounds exist largely in the gas phase at typical atmospheric conditions and are important I-SOA precursors as their oxidation can produce compounds with lower vapour pressures. Overall, $65 \%$ of the emitted POA is coming from mobile diesel sources with the rest emitted by mobile gasoline $(15 \%)$, area $(10 \%)$, and point $(10 \%)$ sources, indicating that the modeled primary organic mass is dominated by mobile sources. Anthropogenic SOA precursors are mainly emitted by area and mobile gasoline sources. Aromatic VOC emissions consist of $48 \%$ vehicle exhaust (35\% gasoline and $13 \%$ diesel), $40 \%$ area, and $12 \%$ point emission sources. The large fraction of mobile sources to total emitted organic compounds is consistent with the results of Stone et al. (2008). Moreover, Wöhrnschimmel et al. (2010) identified vehicle exhaust as one of the principal emission sources of VOCs, accounting for the $32 \%$ (during night) to $62 \%$ (during day) of the total measured VOC concentration. 


\subsection{Boundary conditions}

The values of the OA concentrations at the boundaries of the domain, approximately $8 \mu \mathrm{g} \mathrm{m}^{-3}$ in the west, $11.5 \mu \mathrm{g} \mathrm{m}^{-3}$ in the east, $7 \mu \mathrm{g} \mathrm{m}^{-3}$ in the south and $5 \mu \mathrm{g} \mathrm{m}^{-3}$ in the northern boundary, were chosen based on results of the GISSII' global CTM for March (Racherla and Adams, 2006). All concentrations in this paper are under ambient pressure and temperature conditions. These levels represent the average OA concentrations over the Central Mexican Plateau approximately $100 \mathrm{~km}$ outside Mexico City and should not be confused with the larger-scale background concentrations of Mexico (reflecting concentrations over the lower to middle troposphere over the Pacific Ocean) of much less than $0.5 \mu \mathrm{g} \mathrm{m}^{-3}$ (DeCarlo et al., 2008; Fast et al., 2009). $32 \%$ of the OA concentration at the boundaries of the domain is assumed to be $0.04-0.08 \mu \mathrm{m}$ in size, $24 \%$ is the 0.08 $0.16 \mu \mathrm{m}$ range, $20 \%$ from 0.16 to $0.31 \mu \mathrm{m}, 12 \%$ from 0.31 to $0.625 \mu \mathrm{m}, 8 \%$ from 0.625 to $1.25 \mu \mathrm{m}$, and $4 \%$ in the 1.25 $2.5 \mu \mathrm{m}$ range. Because the biomass burning emissions are not included in the current inventory, they are implicitly provided to the model as a part of the boundary conditions. These relatively high boundary condition values are consistent with the findings of Yokelson et al. (2007) suggesting that the fires in the mountainous forests around Mexico City (MC) could produce as much as $80-90 \%$ of the primary fine particle mass in the MC area. DeCarlo et al. (2010) reported that $\mathrm{OA}$ arising from open $\mathrm{BB}$ represents around $65 \%$ of the $\mathrm{OA}$ mass in the basin and contributes similarly to OA mass in the outflow. Crounse et al. (2009) estimated that biomass burning contributed two thirds of the organic aerosol to the study area in March 2006. Subsequent atmospheric oxidation of co-emitted hydrocarbons can yield low vapor pressure compounds that condense on the existing particulate forming secondary organic aerosol. Therefore, the organic mass transported into the domain is assumed to be a mixture of aged primary and secondary organic aerosols, and is referred to hereafter as "long range transport oxygenated OA" (LT-OOA). The model assumes that V-SOA, I-SOA and S-SOA form a pseudo-ideal solution together with the LT-OOA, which are assumed to be non-reactive and nonvolatile, and therefore, are allowed to partition into this pre-existing organic aerosol.

\subsection{Ground observations}

To evaluate the model results for the OA components within the city basin during March 2006 we used AMS measurements of submicron aerosols collected at two supersites at the Instituto Mexicano del Petroleo (designed as T0) and Universidad Tecnologica de Tecamac (T1). The T0 monitoring station was located to the northwestern part of the basin of Mexico City. It is an urban background site influenced by road traffic emissions ( $300 \mathrm{~m}$ from four major roads surrounding it), domestic and residential emissions, but also potentially influenced by local industrial emissions and from

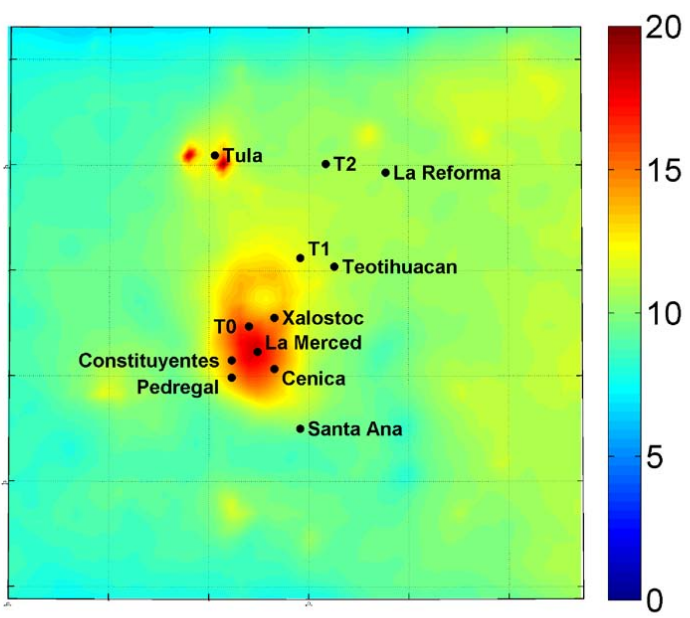

Fig. 2. Predicted average ground level concentrations of $\mathrm{PM}_{1}$ organic mass $\left(\mu \mathrm{g} \mathrm{m}^{-3}\right)$ during 4-30 March 2006.

the Tula industrial area $(60 \mathrm{~km}$ to the north-northwest, in the Hidalgo State). T1 was a suburban background site located around $50 \mathrm{~km}$ to the north of Mexico City, in an area isolated from major urban agglomerations but close to small populated agglomerations, and around $500 \mathrm{~m}$ from the closest road. Data collected by the Aerodyne Mobile Laboratory located on an elevated site of Pico de Tres Padres (PTP, $900 \mathrm{~m}$ above city ground), a mountain within the MCMA, are also used for comparisons of model predictions against OOA and HOA. PTP is $10 \mathrm{~km}$ northeast of "T0" and $19 \mathrm{~km}$ southwest of "T1". The AMS at T0 was a high-resolution time-of flight AMS (DeCarlo et al., 2006) while those at the other two sites were compact time-of-flight versions (Drewnick et al., 2005) which report unit mass resolution data. Detailed analyses and intercomparisons of the AMS data are reported in other publications (Aiken et al., 2010, 2009; Herndon et al., 2008; Yu et al., 2009; de Gouw et al., 2009; Wood et al., 2010). The AMS spectra were analyzed with the PMF technique (Paatero and Tapper, 1994) as described by Ulbrich et al. (2009) and Aiken et al. (2009). Moreover the model predictions of total OA were also compared against measurements at Rancho La Bisnaga, north of Tizayuca in the State of Hidalgo (T2 site) which is a regional background site located around $90 \mathrm{~km}$ to the north of the city of Mexico, in the surroundings of a farm isolated from major urban agglomerations, and around $2 \mathrm{~km}$ from the closest road. In this site the OC was measured by a Sunset Labs. OC/EC analyzer (Birch and Cary, 1996). Detailed analyses of the measurements and description of the used instruments can be found in Doran et al. (2007). AMS measurements were not collected at this site and therefore the model evaluation was limited to the total OA comparison. The location of the monitor sites used is shown in Fig. 1. 

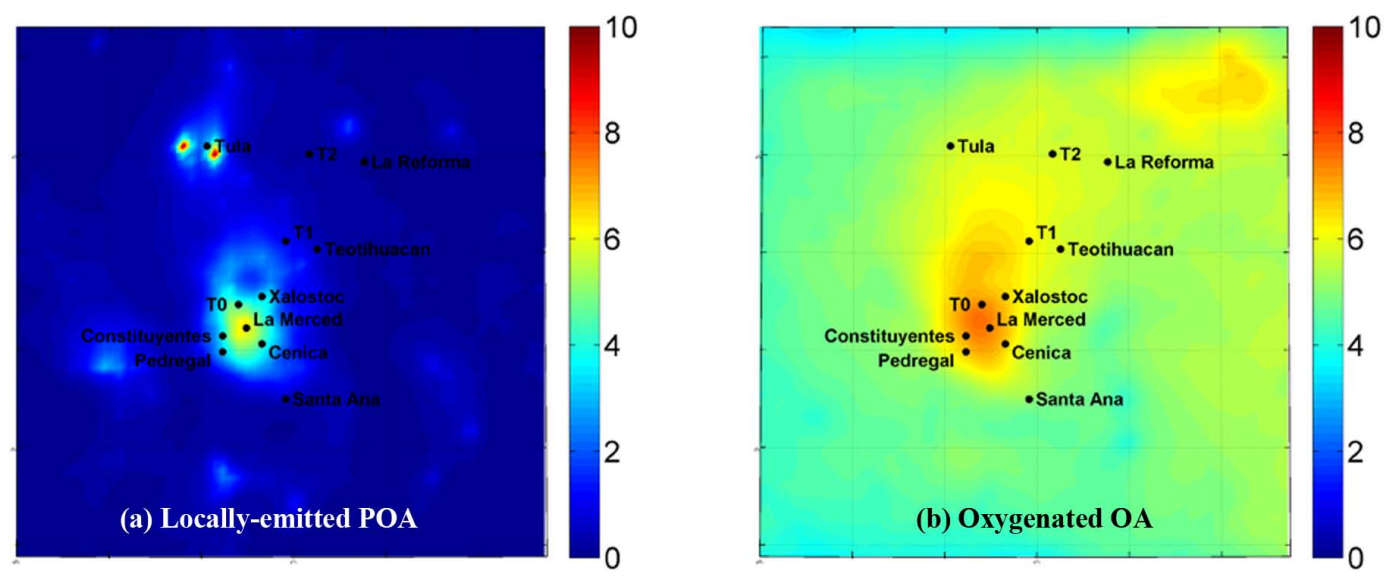

Fig. 3. Average predicted $\mathrm{PM}_{1}$ (a) primary and (b) oxygenated organic aerosol concentrations $\left(\mu \mathrm{g} \mathrm{m}{ }^{-3}\right)$ at the ground level.

\section{Overview of model predictions}

The predicted average ground-level concentration of $\mathrm{PM}_{1}$ organic mass over the period of March 2006 is shown in Fig. 2. The organic mass peak values (approximately $20 \mu \mathrm{g} \mathrm{m}^{-3}$ ) are in the center of Mexico City and in the Tula industrial area. The predicted organic mass concentration is the sum of the predicted concentration of primary organic aerosols which have been emitted in the atmosphere as particles (locally-emitted POA) (Fig. 3a) and the predicted concentrations of the oxygenated organic aerosol (Fig. 3b) that has been created in the atmosphere through chemical reactions and corresponds to the sum of PMCAMx-2008 S-SOA, ISOA, V-SOA, and LT-OOA. The primary organic aerosol concentration is high in the center of Mexico City and in Tula, while it decreases rapidly from its sources mainly due to dilution and evaporation. As an example in the T0 urban site the predicted average locally-emitted primary organic concentration is $4.4 \mu \mathrm{g} \mathrm{m}^{-3}$ while in the $\mathrm{T} 1$ suburban site it decreases to $1.2 \mu \mathrm{g} \mathrm{m}^{-3}$ and in the $\mathrm{T} 2$ rural site is lower than $1 \mu \mathrm{g} \mathrm{m}^{-3}$. These results are consistent with the findings of Querol et al. (2008) where carbonaceous compounds accounted for a significant proportion of fine PM at the urban and industrial sites (around 50\%) and were markedly decreased at the suburban and rural sites $(30 \%)$. On the contrary, the predicted oxygenated organic aerosol concentration has a relatively more uniform spatial distribution with high values in the entire domain (Fig. 3b). The highest values are predicted in the center of Mexico City (up to $7.5 \mu \mathrm{g} \mathrm{m}^{-3}$ ), coming mainly from anthropogenic sources, and in the northeast corner of the domain, mainly from biogenic sources. In the suburban and rural areas, such as $\mathrm{T} 1$ and $\mathrm{T} 2$, the predicted oxygenated $\mathrm{OA}$ is also high, with concentrations around $6 \mu \mathrm{g} \mathrm{m}^{-3}$. Anthropogenic V-SOA, I-SOA, and S-SOA, are predicted to be more photochemically processed and less volatile downwind of the Mexico City center. In particular at T0 locally-produced OA consists of $60 \%$ POA and $40 \%$
OOA. At T1 and T2, OOA corresponds to $60 \%$ and $85 \%$ of locally-produced OA respectively. The domain-average contribution of OOA to locally-produced OA is $68 \%$. Observational studies during the MILAGRO campaign also support the predicted spatial distribution of OOA. DeCarlo et al. (2008) calculated the $\mathrm{O} / \mathrm{C}$ atomic ratio for $\mathrm{OA}$ and found a clear increase with photochemical age. Yu et al. (2009) found that the majority of organic carbon particles at $\mathrm{T} 1$ and $\mathrm{T} 2$ were secondary (an average of $63 \pm 17 \%$ and $67 \pm 12 \%$ respectively). The geographic distribution of photochemical age and CO was also examined by Kleinman et al. (2008), confirming that Mexico City is a major source region for the area and that pollutants become more dilute and aged as they are advected towards T1 and T2. Finally, V-SOA is predicted to be the dominant component of OOA (accounting for $84 \%$ of the locally produced OOA) as the emission rate of its precursors (anthropogenic and biogenic VOCs) is more than ten times higher than the I-VOC and S-VOC emission rate (Table 1). I-SOA concentration ( $3 \%$ of OOA) is lower than the S-SOA (13\% of OOA) as the saturation concentration of its precursors is between $10^{3}$ and $10^{6} \mu \mathrm{g} \mathrm{m}^{-3}$ and requires a few generations of aging before its volatility is reduced enough to allow its partitioning into the particulate phase.

\section{Model performance evaluation}

The results of the comparison of model predictions with the OA observations are depicted in Figs. 4 and 5. The model does a reasonable job most of the time reproducing the observations in T0, which is located in the urban center of Mexico City (Fig. 4a). Nevertheless, the model is missing a few major spikes which appear early in the morning such as during the 11th, 18th, and 21st of the month and are associated with biomass burning events (Aiken et al., 2009). Therefore, these underpredictions are related to the emission inventory currently used, which does not contain temporally variable 

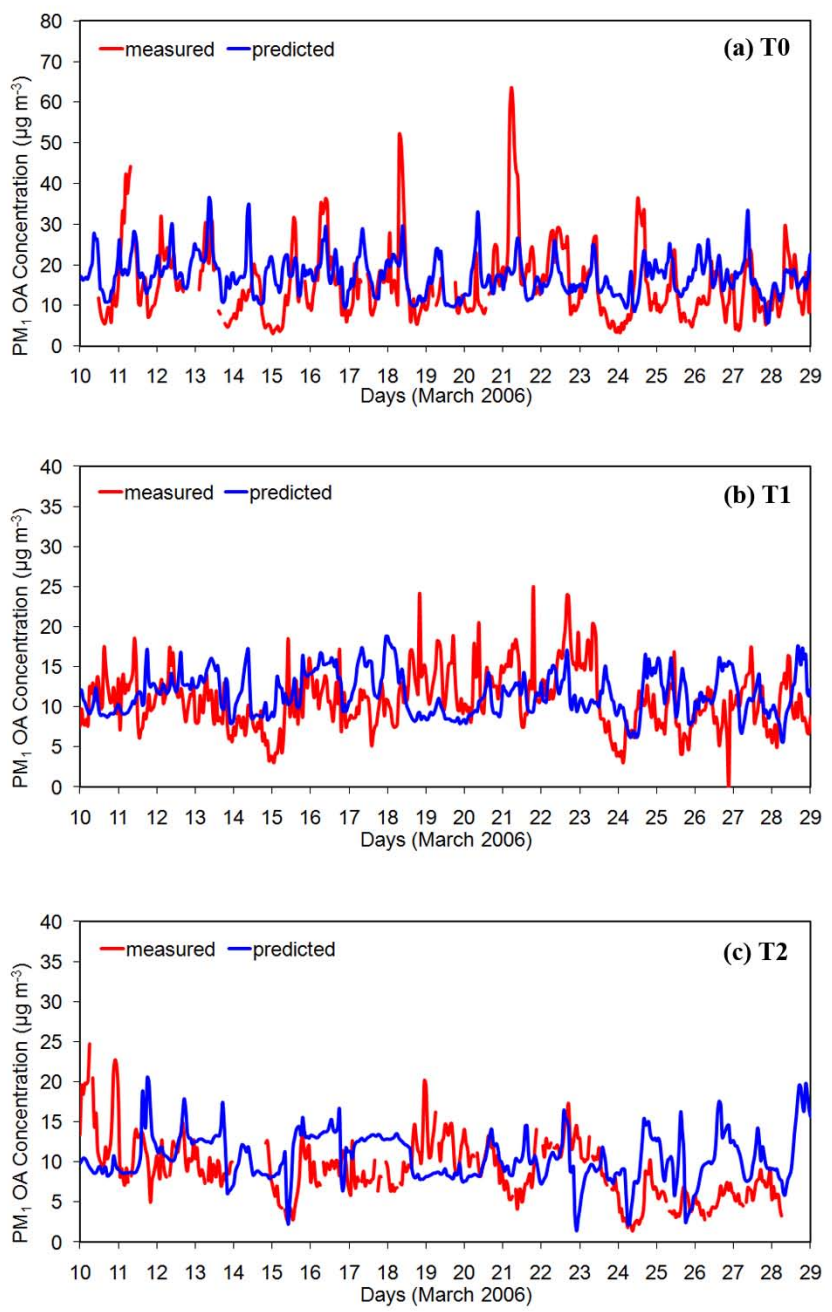

Fig. 4. Comparison of model predictions with hourly measurements for total $\mathrm{PM}_{1}$ organic mass concentration taken during the MILAGRO campaign in March 2006 at (a) T0 (urban site), (b) T1 (suburban site), and (c) T2 (rural site).

biomass burning emissions. These emissions are provided to the model through the boundary conditions which are timeindependent. Both measurements and predictions though, suggest that organic mass has a high variation during the day. Organic mass concentrations are almost always higher than $10 \mu \mathrm{g} \mathrm{m}^{-3}$, while during morning hours often exceed $25 \mathrm{\mu g} \mathrm{m}^{-3}$. Furthermore, the average predicted $\mathrm{PM}_{1}$ OA concentration in PTP, which is located $10 \mathrm{~km}$ northeast of T0, is $13.6 \mu \mathrm{g} \mathrm{m}^{-3}$ while the corresponding measured value is $10 \mu \mathrm{g} \mathrm{m}^{-3}$. Overall, the OA predictions at $\mathrm{T} 0$ are within $50 \%$ of the measurements for $57 \%$ of the data points and within $30 \%$ for $41 \%$ of the time (Fig. 5).

In T1, which is a suburban site, the variation of organic mass concentrations is smaller than and not as regular as in T0 (Fig. 4b). Most of this mass is coming from other areas and therefore depends mostly on the weather conditions. The

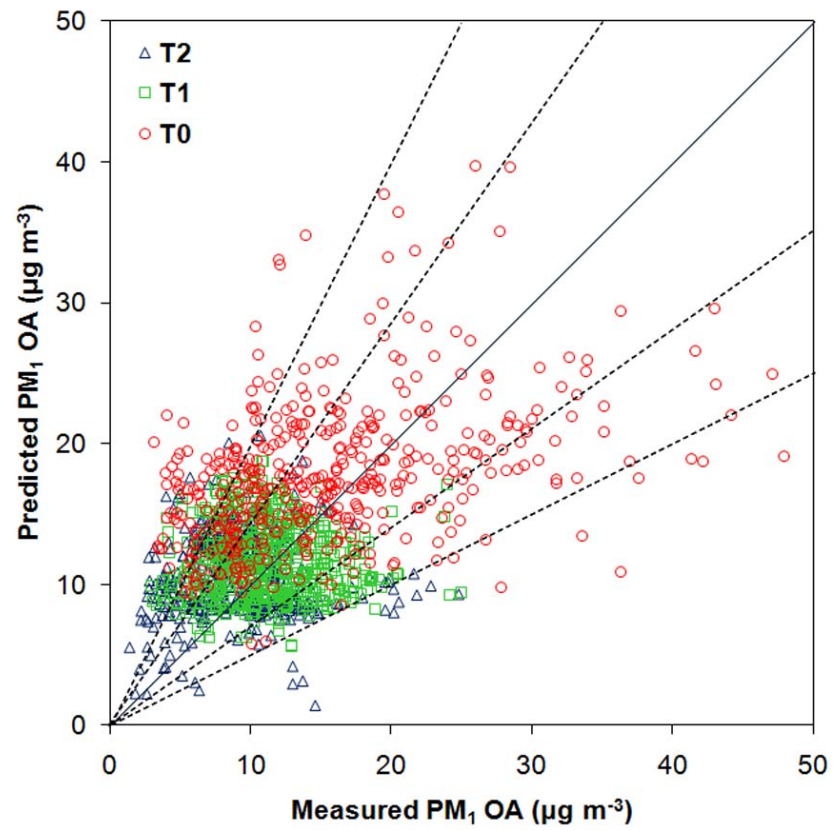

Fig. 5. Comparison of predicted hourly average OA concentrations against observational data from T0, T1, and T2 measurement sites. Also shown are the $1: 1, \pm 30 \%$, and $\pm 50 \%$ lines.

model is able to reproduce the measured values within a few $\mu \mathrm{g} \mathrm{m}^{-3}$ most of the time with concentrations ranging from 7 to $20 \mu \mathrm{g} \mathrm{m}^{-3}$. Nevertheless PMCAMx-2008 underpredicts the organic mass during the period from the 18th to the 20th of the month. These are the days with the most favorable wind directions for T0-T1-T2 transport (Fast et al., 2007). The analysis of the measurements suggests that the organic mass produced in Mexico City center during the morning of 18th was transported to the north and appeared in T1 during the afternoon of the same day. On the other hand, the predictions in $\mathrm{T} 1$ show a reduction in organic mass during that day indicating inaccuracies by the meteorological simulations during this period. Errors in these inputs to PMCAMx result in corresponding problems in its predictions. Overall, the OA predictions at T1 are within $50 \%$ of the measurements for $82 \%$ of the data points and within $30 \%$ for $51 \%$ of the time (Fig. 5).

In the rural site $\mathrm{T} 2$ both the measured and predicted average OA concentrations are approximately $10-20 \%$ lower than the corresponding values at T1 (Fig. 4c). Given the dilution expected during the transport of Mexico City originating OA between the two sites, this small decrease in OA concentrations is rather surprising. According to PMCAMx it reflects the ongoing generation of OOA and the importance of regional sources in this region. The dynamic range of $\mathrm{OA}$ in $\mathrm{T} 2$ is less than in T1. Overall, the model behavior is satisfactory on average but it cannot reproduce the daily variations of organic mass accurately. T2 is close to the north boundary of the model domain and given that the used boundary 


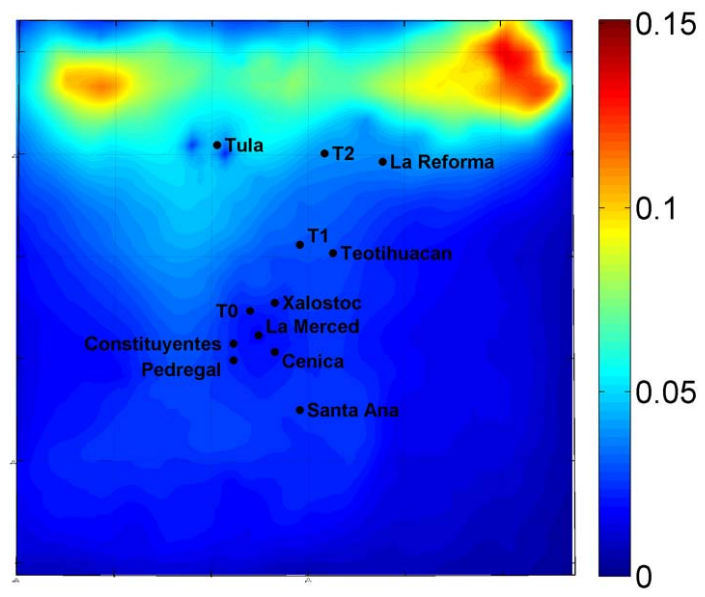

Fig. 6. Fractional contribution of locally-produced biogenic SOA to total OA at the ground level.

conditions are time-independent, the model cannot predict the hourly variations caused from sources north of the T2 site. Overall, the OA predictions at T2 are within $50 \%$ of the measurements for $64 \%$ of the data points and within $30 \%$ for $37 \%$ of the time (Fig. 5).

The biogenic V-SOA PMCAMx predictions tend to be a little lower than the Stone et al. (2010) measurement-based estimates of biogenic SOA at T0 and T1. The simulated biogenic V-SOA concentrations range from 0.1 to $1.1 \mu \mathrm{g} \mathrm{m}^{-3}$ at $\mathrm{T} 0$ and from 0.1 to $1.4 \mu \mathrm{g} \mathrm{m}^{-3}$ at $\mathrm{T} 1$. The measurementbased estimates range from 0.4 to $1.8 \mu \mathrm{g} \mathrm{m}^{-3}$ at $\mathrm{T} 0$ and from 0.4 to $2.2 \mu \mathrm{g} \mathrm{m}^{-3}$ at $\mathrm{T} 1$. Some of the difference could be explained by biogenic SOA transported into the domain by elsewhere and not resolved by the model. These results suggest that biogenic SOA levels in the Mexico City region are far from negligible. In particular, the relative contribution of locally-produced biogenic V-SOA to total OA is predicted to be up to $15 \%$ north of Mexico City (Fig. 6). The PMCAMx-predicted contribution of locally-produced biogenic V-SOA to locally-produced total SOA (sum of V-SOA, I-SOA, and S-SOA) is $20-30 \%$ within the city and up to $70 \%$ at the surrounding areas. Hodzic et al. (2009) estimated the relative contribution of biogenic SOA to the predicted monthly levels of SOA, to be more than $30 \%$ at the city center and up to $65 \%$ at the regional scale.

\subsection{Diurnal average profiles}

The predicted and measured diurnal average OA concentration profiles at T0, T1, and T2 sites during MILAGRO are depicted in Fig. 7. These averages depend less on the day to day variability of the meteorology and the emissions and more on the major processes affecting the OA concentrations. In all cases, the model predictions are in agreement within experimental error with the measurements. The diurnal profile at the urban site T0 (Fig. 7a) has two peaks; the major one dur-
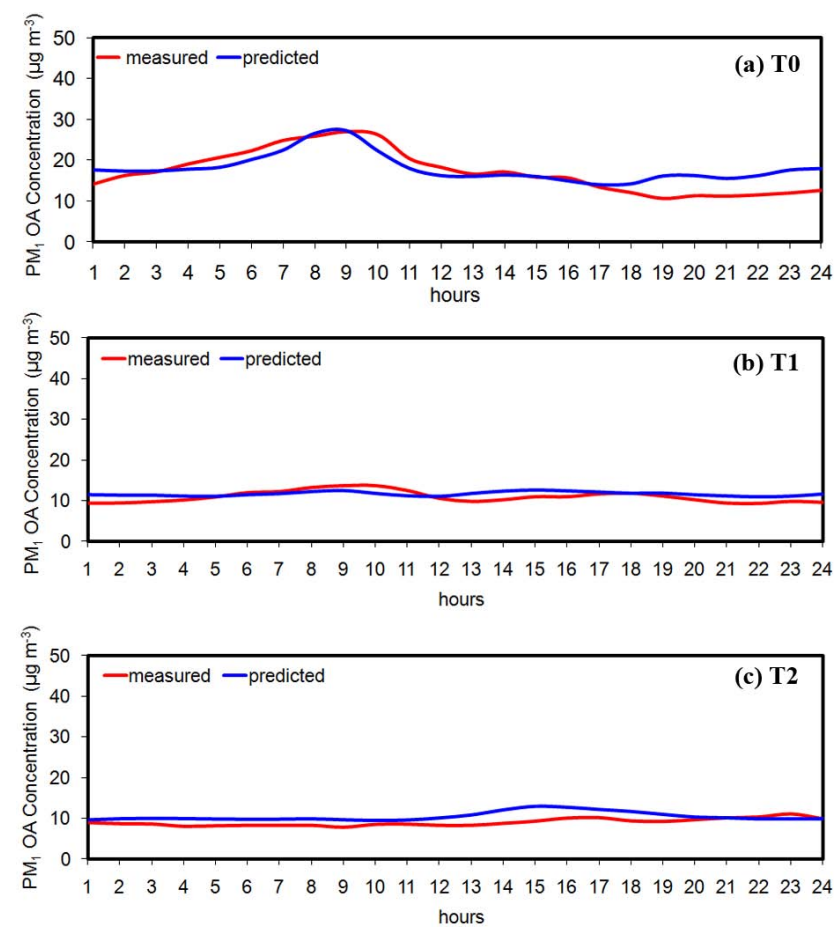

Fig. 7. Comparison of model diurnal predictions with hourly measurements for total $\mathrm{PM}_{1}$ organic aerosols against measurements taken during the MILAGRO campaign in March 2006 at (a) T0 (urban site), (b) T1 (suburban site), and (c) T2 (rural site).

ing morning, related to the primary emissions, and a second less pronounced peak in the afternoon, mainly due to photochemical processes. The same peaks appear in the diurnal profile of OA at the suburban site T1 (Fig. 7b), the levels of which are smaller compared to those in the T0 site. The first peak is related to the local sources while the peak in the afternoon is caused by the OA which was transported there from the urban center and the local photochemistry. Finally, both the measured and the predicted organic mass at the rural site T2 (Fig. 7c), increase slightly late in the afternoon mainly due to transport of emissions and also photochemistry. As expected, there is no morning peak, given the absence of local sources in the area around and immediately upwind of $\mathrm{T} 2$.

\subsection{Comparison with PMF analysis}

The AMS spectra were analyzed with the PMF technique (Paatero and Tapper, 1994) as described by Ulbrich et al. (2009) and Aiken et al. (2009) separating total organic aerosol (OA) into hydrocarbon-like organic aerosol (HOA, a POA surrogate), oxidized organic aerosol (OOA, a surrogate for SOA) and biomass burning organic aerosol (BBOA) for T0, T1, and PTP. This specification allows a more in-depth evaluation of modeled OA components as they have different temporal emission and formation patterns. 
HOA appears to have the AMS mass spectral fingerprint for primary combustion particles from urban sources, and also includes particles from other relatively reduced sources such as meat cooking and trash (plastic) burning (Mohr et al., 2009). Therefore the AMS locally-emitted HOA can be compared with the PMCAMx-2008 POA which is the fraction of the emissions that is in the aerosol phase without having undergone any chemical reactions (Fig. 8). At T0, PMCAMx-2008 successfully reproduces the observed HOA variation characterized by an early morning peak associated with traffic (Fig. 8a). These results are in accordance with the findings of De Gouw et al. (2009) who investigated the diurnal variation of hydrocarbons, elemental carbon (EC) and hydrocarbon-like organic aerosol (HOA) which were also dominated by a high peak in the early morning. Both, the average predicted POA concentration and the AMS-HOA concentration during March 2006 at T0 are close to $4.5 \mu \mathrm{g} \mathrm{m}^{-3}$. The agreement is still reasonable at $\mathrm{T} 1$ where the average POA and AMS-HOA concentrations are approximately $1.3 \mu \mathrm{g} \mathrm{m}^{-3}$. However the predicted morning POA peaks $2 \mathrm{~h}$ later than observed (Fig. 8b). At PTP, larger discrepancies between observed and modeled POA values are found. The average predicted POA concentration during March 2006 is $1.7 \mu \mathrm{g} \mathrm{m}^{-3}$ while the PMF analysis resulted in $2.9 \mu \mathrm{g} \mathrm{m}^{-3} \mathrm{HOA}$ during the same period. The predicted morning POA peaks $2 \mathrm{~h}$ earlier than observed (Fig. 7c). The late arrival of the measured pollutants over the elevated PTP site is associated with the growth of the PBL above $900 \mathrm{~m}$ (station's altitude). Therefore, this discrepancy suggests potential problems in describing the vertical mixing in the complex terrain around PTP in the early morning hours.

OOA often contains a more volatile and less processed oxygenated $\mathrm{OA}$ fraction which shows high correlation with photochemical products such as $\mathrm{O}_{3}, \mathrm{O}_{\mathrm{x}}$, glyoxal, and ammonium nitrate (Volkamer et al., 2006, 2007; Aiken et al., 2008; Lanz et al., 2007; Ulbrich et al., 2009; Dzepina et al., 2009). However, a significant fraction of the OOA consists of more oxygenated organics (Aiken et al., 2008) which are assumed here to have initially formed far from Mexico City. Therefore, the AMS OOA is compared with the sum of the PMCAMx-2008 S-SOA, I-SOA, V-SOA, and LT-OOA. Figure 9 presents the comparison of average diurnal profiles of predicted oxygenated organic components and the PMF-estimated OOA at the 3 locations, T0, T1 and PTP. The shape of the OOA diurnal profile features a strong enhancement in concentrations during the morning, associated with an active photochemical production of oxygenated organic aerosols close to the emissions (i.e. T0, PTP), and high concentrations until afternoon. In comparison, De Gouw et al. (2009) also found that species with secondary sources such as OOA and WSOC stayed relatively high in the afternoon indicating strong photochemical formation. The diurnal variability is less pronounced at the peripheral $\mathrm{T} 1$ station and displays a more gradual increase of concentrations during the day. Figure 9 confirms that the predicted oxy-
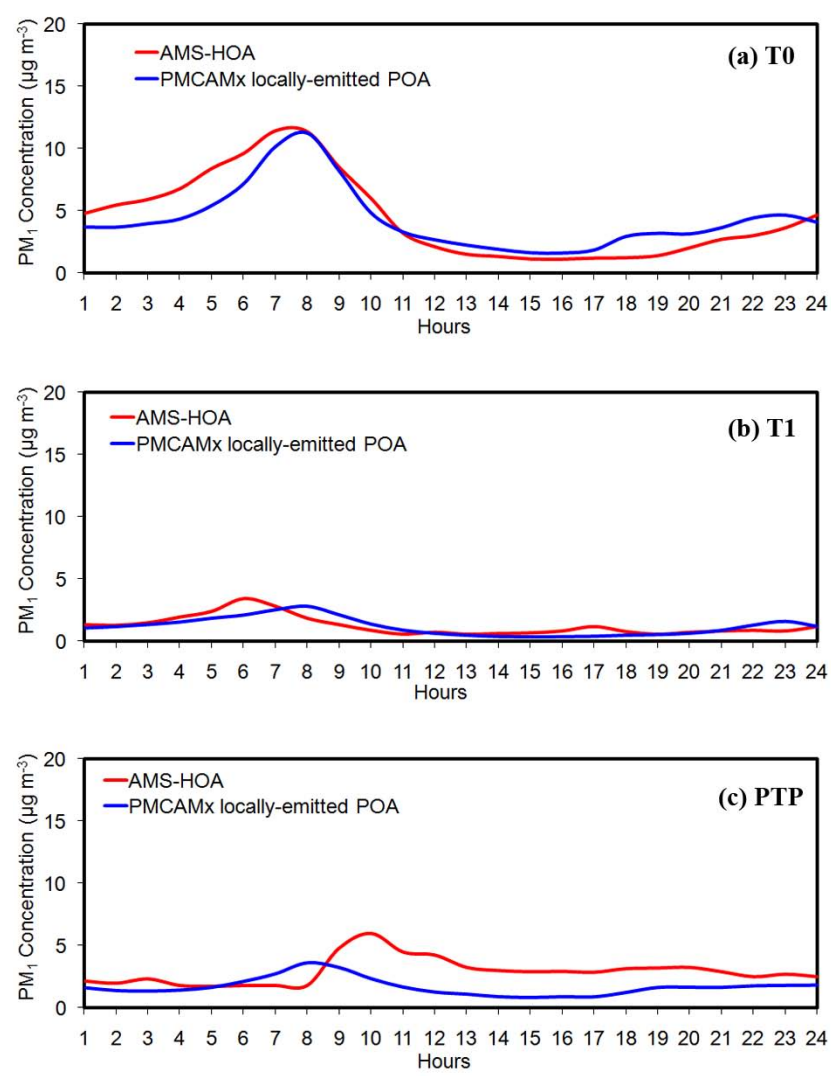

Fig. 8. Comparison of model episode average diurnal predictions for $\mathrm{PM}_{1}$ locally-emitted primary organic aerosols against AMSHOA taken during the MILAGRO campaign in 4-30 of March 2006 at (a) T0, (b) T1 and (c) PTP.

genated organic aerosol values and their associated variability range are in reasonable agreement with the observed ones. Both predicted and observed OOA levels gradually decrease downwind of the city with monthly average concentrations ranging from $7.5 \mu \mathrm{g} \mathrm{m}^{-3}$ at $\mathrm{T} 0$ to $6.3 \mu \mathrm{g} \mathrm{m}^{-3}$ and $4.6 \mu \mathrm{g} \mathrm{m}^{-3}$ at $\mathrm{T} 1$ respectively. At $\mathrm{T} 0$ and PTP the predicted formation of OOA during the early morning hours is not as rapid as the PMF estimates. This discrepancy can be partially attributed to the predicted $\mathrm{OH}$ levels as they are slightly underestimated during early morning even though they are reasonably reproduced by the model during the rest of the day (not shown). A sensitivity study to the HONO emissions used by the model (see Sect. 6) suggests that the HONO production and emissions are relatively important for the production of $\mathrm{OH}$ and SOA in the early morning. The comparison at T1 and PTP suggests a model tendency to overpredict OOA concentration during early afternoon. At PTP the average monthly predicted OOA concentration is $6.6 \mu \mathrm{g} \mathrm{m}^{-3}$ while the PMF analysis resulted in $5.9 \mathrm{\mu g} \mathrm{m}^{-3}$ OOA on average during the same period. Figures 8 and 9 do not include the BBOA and therefore their sum does not correspond to the total predicted OA. 

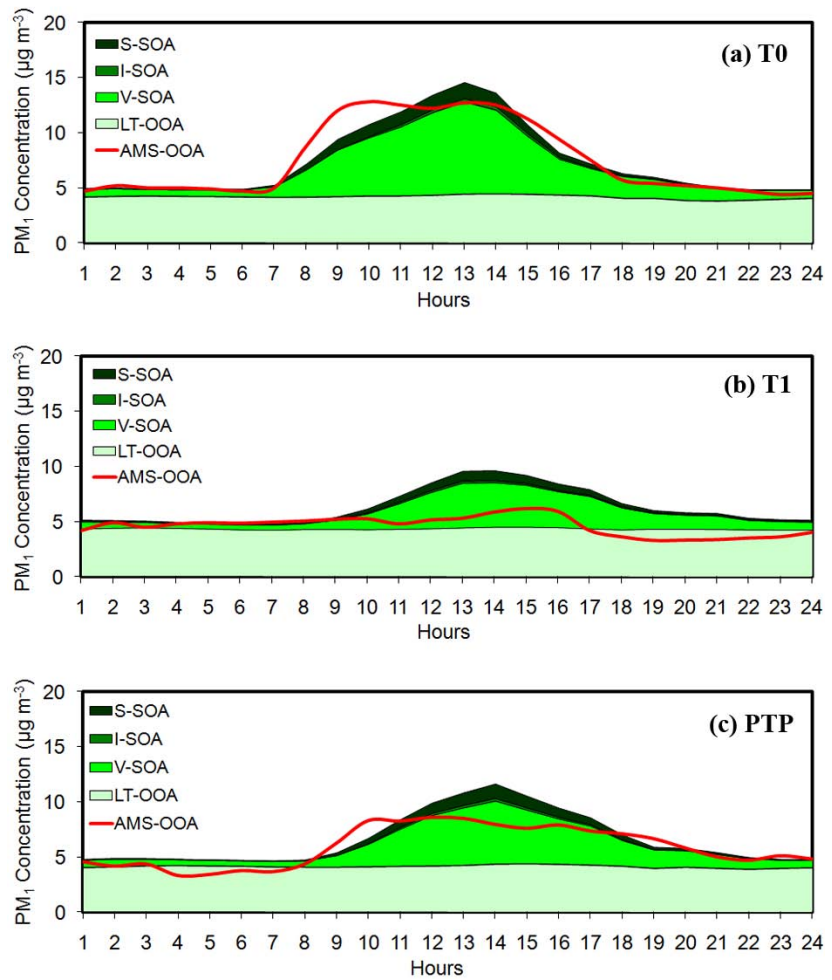

Fig. 9. Comparison of model episode average diurnal predictions for $\mathrm{PM}_{1}$ oxygenated organic aerosols (sum of LT-OOA, V-SOA, ISOA, and S-SOA) against AMS-OOA taken during the MILAGRO campaign in 4-30 March 2006 at (a) T0, (b) T1 and (c) PTP.

Overall, the predicted chemical composition of OA is generally consistent with the PMF analysis results. However, PMCAMx-2008 tends to predict higher oxygenated OA than the PMF analysis. Given that the AMS PMF results are also subject to error this comparison of the predictions of these two methods is quite encouraging. Future simulations though, should use a larger domain along with an accurate biomass burning emission inventory in order to increase the precision not only of the estimated BBOA but also of the SOA produced from fire emitted VOCs, I-VOCs, and SVOCs. Moreover, this study does not estimate explicitly the formation of SOA from very volatile precursors such as glyoxal (Volkamer et al., 2007; Ng et al., 2008). Finally, aqueous phase reactions in clouds (Warneck, 2003; Lim et al., 2005; Liu et al., 2009) and the oligomerization processes of particle-phase semivolatile material (Jang et al., 2002; Kalberer et al., 2004; Iinuma et al., 2004) that can lead to continued SOA growth are also not taken into account. There are several potential explanations for this result. The first is that these formation pathways were not major OA sources during the study period. The second is that their effects are indirectly included in our parameterization of the production of SOA and its subsequent aging. The third one is that other sources are overestimated in the model (especially

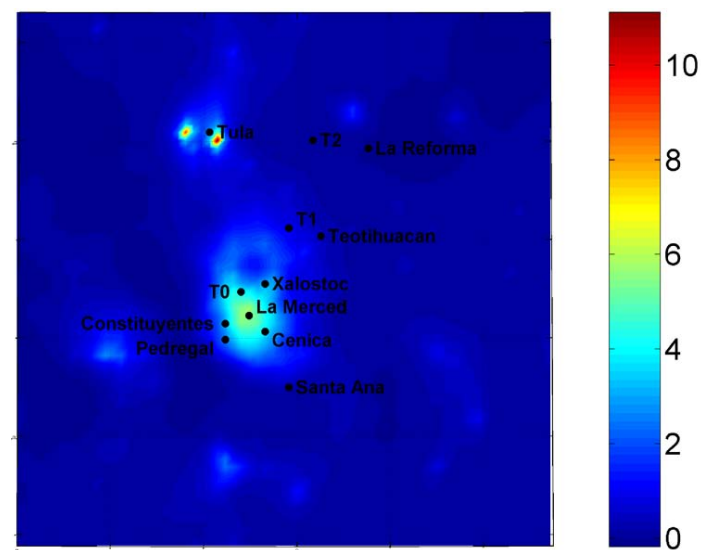

Fig. 10. Predicted increase in ground-level concentrations $\left(\mu \mathrm{g} \mathrm{m}^{-3}\right)$ of the $\mathrm{PM}_{1}$ POA after using a lower volatility distribution of OA primary emissions.

the boundary conditions). There is a good chance that all of them are at least partially true. Cloud processes probably had a small effect on locally produced OA because both of the low cloud cover during the study and the spatial and temporal scales involved in this process for an urban area. Clouds could have been involved of course in the formation of OA transported into the city from outside the modeling domain. The role of glyoxal and methylglyoxal in OA production in this episode has been recently investigated by $\mathrm{Li}$ et al. (2011). They reported a relatively small contribution (10\% of the SOA inside the city and $4 \%$ outside) which would not affect our results significantly. We believe that the oligomerization effects are probably indirectly included in our aging mechanism.

\section{Sensitivity analysis}

Uncertain inputs for the organic aerosol module include the volatility distribution for the organic aerosol emissions and the rate constant used for the aging reactions of SOA vapors with hydroxyl radicals. A simulation based on a low emissions' volatility case, where the emissions in the low volatility bins $\left(\mathrm{C}^{*}: 10^{-2}-10^{2} \mu \mathrm{g} \mathrm{m}^{-3}\right)$ are doubled and the emissions in the high volatility bins are set to 0 , was conducted in order to investigate the sensitivity of the model predictions to changes on the volatility distribution of the OA emissions. Using the low volatility distribution, the partition of the emissions favors the particulate phase. In this case, PMCAMx predicts that the locally-emitted POA (emissions that did not undergo any chemical reaction) is two times higher than using the base case distribution (Fig. 10). In particular, POA increases from $4.4 \mu \mathrm{g} \mathrm{m}^{-3}$ to $8.5 \mu \mathrm{g} \mathrm{m}^{-3}$ at $\mathrm{T} 0$, from $1.2 \mu \mathrm{g} \mathrm{m}^{-3}$ to $2.2 \mu \mathrm{g} \mathrm{m}^{-3}$ at $\mathrm{T} 1$, and from $0.25 \mu \mathrm{g} \mathrm{m}^{-3}$ to $0.5 \mu \mathrm{g} \mathrm{m}^{-3}$ at $\mathrm{T} 2$. The corresponding measurements were $4.5 \mu \mathrm{g} \mathrm{m}^{-3}$ at $\mathrm{T} 0$ and $1.3 \mu \mathrm{g} \mathrm{m}^{-3}$ at $\mathrm{T} 1$. 


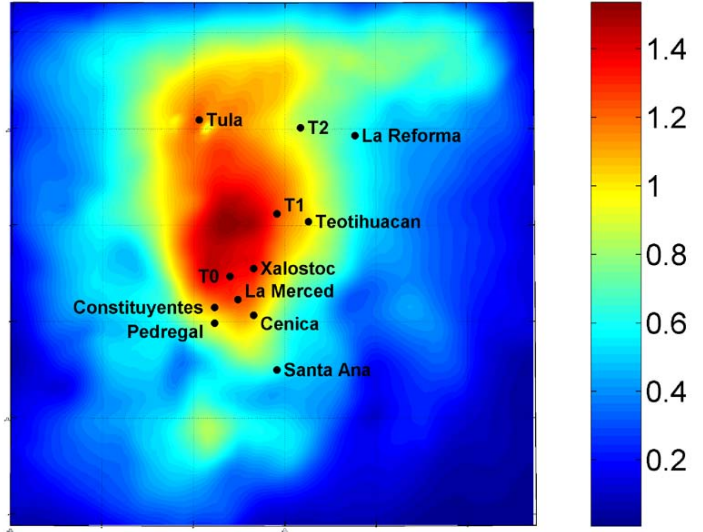

Fig. 11. Predicted increase in ground-level concentrations $\left(\mu \mathrm{g} \mathrm{m}^{-3}\right)$ of the $\mathrm{PM}_{1}$ OOA after using a rate constant equal to $k(298 \mathrm{~K})=10 \times 10^{-11} \mathrm{~cm}^{3} \mathrm{molec}^{-1} \mathrm{~s}^{-1}$ for S-SOA, I-SOA and VSOA aging reactions.

These discrepancies between the two simulations indicate that the assumed volatility distribution of the emissions has a significant impact on the predicted POA concentrations. Using the low volatility distribution, the model significantly overpredicts the HOA concentrations at $\mathrm{T} 0$ and $\mathrm{T} 1$, indicating that the base case distribution is more appropriate for the description of the primary organic aerosols in the Mexico City Basin.

The sensitivity of the predicted OOA to the aging reaction constant was investigated by using a rate constant equal to $k(298 \mathrm{~K})=10 \times 10^{-11} \mathrm{~cm}^{3} \mathrm{molec}^{-1} \mathrm{~s}^{-1}$ for S-SOA, I-SOA and V-SOA. The higher oxidation constant used resulted in higher OOA concentrations by $20 \%$ in Mexico City and Tula vicinity (Fig. 11). At T0, OOA increased from $7.5 \mu \mathrm{g} \mathrm{m}^{-3}$ to $9.1 \mu \mathrm{g} \mathrm{m}^{-3}$ resulting in an overprediction of OOA, compared to PMF analysis results, during the afternoon (Fig. 12). This increase is due more to increased S-SOA and I-SOA levels (three times higher concentrations than the base case) and less at V-SOA (increased by $10 \%$ ). At T0, the fraction of biogenic to total locally-produced V-SOA is approximately 20$30 \%$. Therefore this small increase on V-SOA concentration is attributed more to the low sensitivity of V-SOA to the aging rate than to the levels of the biogenic V-SOA in the domain. Moreover, this result suggests that the potential of the I-VOC and S-VOC to form SOA is high and the rate constant of their photochemical aging is quite important. Nevertheless, the $\mathrm{S}$ SOA and I-SOA are only a small portion of the predicted locally-produced OA (5-10\%) in MCMA. Therefore, even if their concentration tripled after using the higher oxidation constant, the locally-produced OA increased by $15 \%$ at $\mathrm{T} 0$.

To examine the effect of the HONO emissions used in this application (as discussed in Sect. 3) on the predicted OOA, a simulation excluding these emissions was conducted. The results of this sensitivity analyses indicate that the inclusion of HONO to the emissions inventory is indirectly responsi-

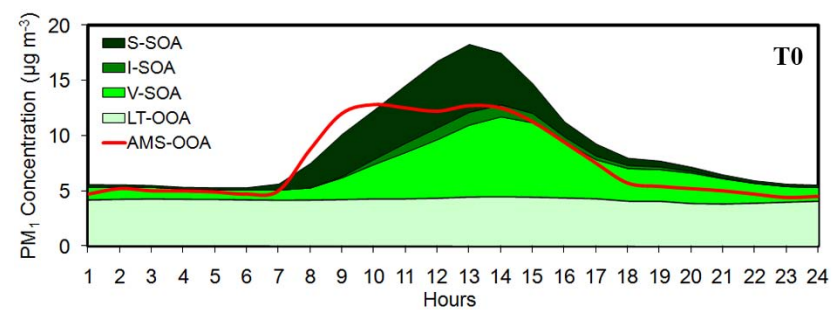

Fig. 12. Comparison of model episode average diurnal predictions in high aging reaction case for $\mathrm{PM}_{1}$ oxygenated organic aerosols (sum of LT-OOA, V-SOA, I-SOA, and S-SOA) against AMS-OOA taken during the MILAGRO campaign in 4-30 March 2006 at T0.

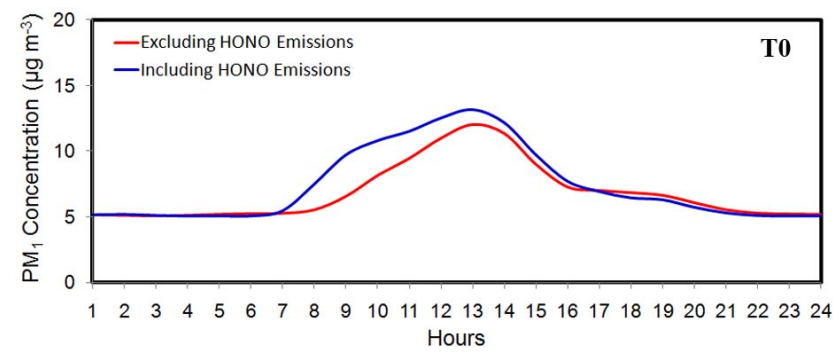

Fig. 13. Comparison of model episode average diurnal predictions for $\mathrm{PM}_{1}$ oxygenated organic aerosols at $\mathrm{T} 0$ using an emission inventory with HONO emissions (red line) and without HONO emissions (blue line).

ble for $3 \%$ and $10 \%$ of the predicted OOA in the Mexico City center and the Tula area respectively. Nevertheless, the HONO emissions and formation appeared to be relatively important for the early morning production of the OOA in the center of Mexico City as it photodissociates upon sunrise to inject a pulse of $\mathrm{OH}$ into the early morning atmosphere. At T0, the model, taking into account the HONO emissions, predicts that the formation of OOA starts to be significant at 7 a.m., while excluding these emissions, the formation of OOA is delayed for one hour and starts at 8 a.m. (Fig. 13). The increase of the predicted OOA during $7 \mathrm{a} . \mathrm{m}$. to $12 \mathrm{p} . \mathrm{m}$. after the inclusion of HONO to the emission inventory is $25 \%$ on average at $\mathrm{T} 0$.

The sensitivity of the results to the boundary conditions of $\mathrm{OA}$ and the corresponding long range transport was also tested. A $50 \%$ reduction of the OA boundary conditions resulted in an almost linear response of the background organic concentration, which is not surprising since this OA is assumed to be non-reactive and nonvolatile. The influence of the long range transport concentration remains significant for the low boundary condition case as it represents approximately $20 \%$ of the total organic aerosol concentration at Mexico City center. Figure 14 shows the comparison between the measured and the predicted total organic mass concentrations at $\mathrm{T} 0, \mathrm{~T} 1$, and $\mathrm{T} 2$ for lower boundary conditions during March 2006. In this case, the model tends to 

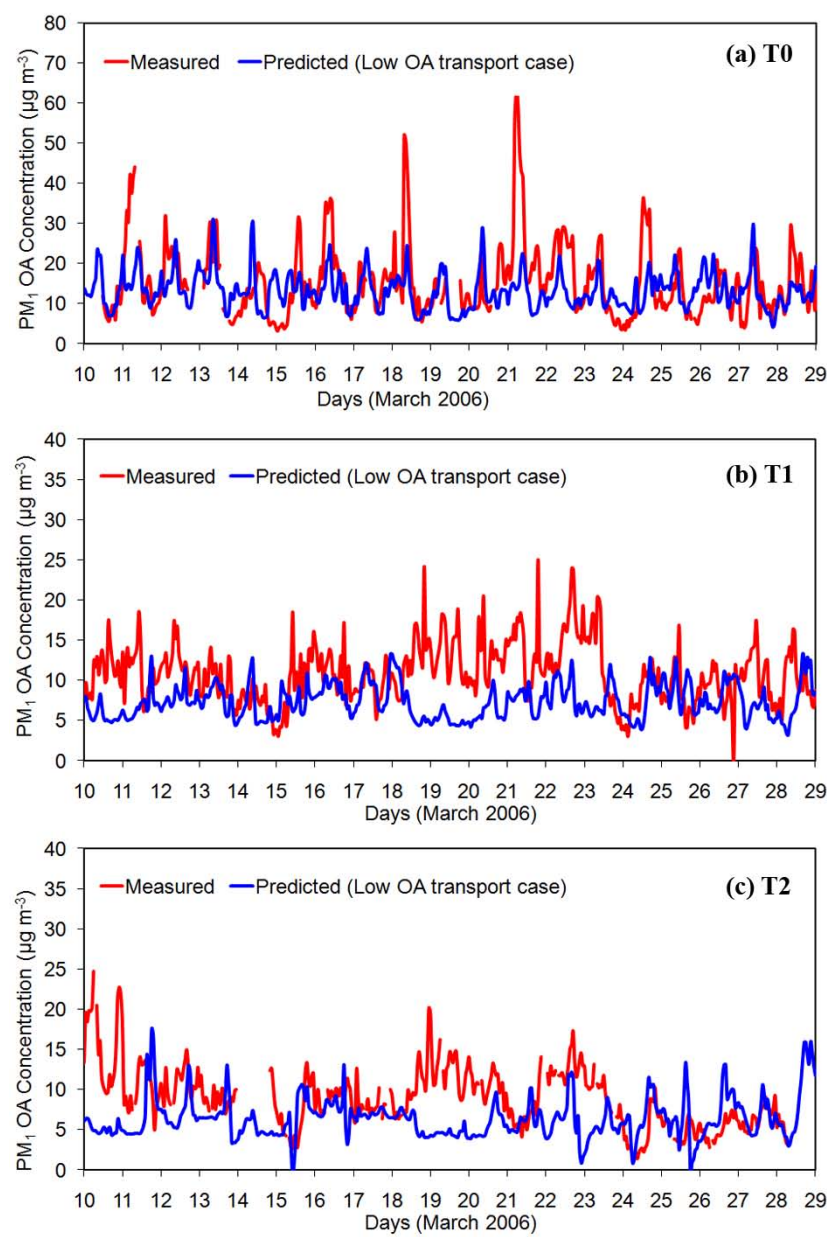

Fig. 14. Comparison of model predictions in the low boundary conditions case with hourly measurements for total $\mathrm{PM}_{1}$ organic mass concentration taken during the MILAGRO campaign in March 2006 at (a) T0 (urban site), (b) T1 (suburban site), and (c) T2 (rural site) on ground level.

underpredict the observed OA on 18-21 March in all three sites, while the agreement improves for 24-29 March. During the first period, high biomass activities were observed, while during the latter, the fire emissions were the lowest of the month. Therefore, each set of boundary conditions performs better in different time periods, and an accurate biomass burning emission inventory is necessary, or at least, the boundary conditions should be variable in time. Overall, the model using the base case boundary conditions set has a better performance in all three measurement sites than using the lower boundary conditions set. In particular, the base case set results in an overprediction of $\mathrm{OM}$ with mean bias $1.9 \mu \mathrm{g} \mathrm{m}^{-3}, 0.8 \mu \mathrm{g} \mathrm{m}^{-3}$, and $1.5 \mu \mathrm{g} \mathrm{m}^{-3}$ at $\mathrm{T} 0, \mathrm{~T} 1$, and $\mathrm{T} 2$ sites respectively. On the other hand, the lower boundary conditions set underpredicts the $\mathrm{OM}$ with mean bias $-2.3 \mu \mathrm{g} \mathrm{m}^{-3},-3.5 \mu \mathrm{g} \mathrm{m}^{-3}$, and $-2.7 \mu \mathrm{g} \mathrm{m}^{-3}$ at $\mathrm{T} 0, \mathrm{~T} 1$, and $\mathrm{T} 2$ sites respectively.

\section{Conclusions}

In this work PMCAMx-2008, which accounts for volatility partitioning and aging of primary and secondary organic aerosols, was applied in the Mexico City Metropolitan Area during the MILAGRO-2006 campaign. The model performance was evaluated against measurements from four different types of sites, an urban site (T0), a suburban site (T1), a rural site (T2), and an elevated site (PTP). The model predictions are compared with PMF analysis of AMS observations taken at T0, T1, and PTP sites and with hourly measurements taken at T0, T1, and T2 sites during the MILAGRO 2006 campaign.

The highest concentration of $\mathrm{OM}$ is predicted to be in Mexico City urban center and in the Tula area (approximately $20 \mu \mathrm{g} \mathrm{m}^{-3}$ ). The OA concentration decreases with distance from its source areas due to dilution and evaporation. At T0, total $\mathrm{OA}$ consists of $4.4 \mu \mathrm{g} \mathrm{m}^{-3} \mathrm{POA}$ and $7.5 \mu \mathrm{g} \mathrm{m}^{-3}$ OOA while at T1 the contribution of POA and OOA to total OA is $1.2 \mu \mathrm{g} \mathrm{m}^{-3}$ and $6.3 \mu \mathrm{g} \mathrm{m}^{-3}$ respectively. The rest of the OA mass $\left(6.1 \mu \mathrm{g} \mathrm{m}^{-3}\right.$ and $4.2 \mu \mathrm{g} \mathrm{m}^{-3}$ in $\mathrm{T} 0$ and $\mathrm{T} 1$ respectively) is assumed to originate from biomass burning activities. High oxygenated OA concentrations are predicted for a significant part of the domain. In particular at T0 locally-produced OA consists of $60 \%$ locallyemitted POA and $40 \%$ locally-produced OOA. At T1 and T2, OOA corresponds to $60 \%$ and $85 \%$ of locally-produced $\mathrm{OA}$ respectively. The domain-average contribution of OOA to locally-produced $\mathrm{OA}$ is $68 \%$. The highest OOA values are predicted in and around Mexico City center (anthropogenic sources) and in the northeast of the domain (biogenic sources). V-SOA is predicted to be the dominant component of OOA (accounting for $84 \%$ of the locally-produced OOA) following by S-SOA (13\% of OOA) and I-SOA ( $3 \%$ of OOA).

The model is doing a reasonable job most of the time in all measurement sites (T0, T1, and T2). Overall, the OA predictions are within $50 \%$ of the measurements for $68 \%$ of the data points and within $30 \%$ for $44 \%$ of the time. The comparison of observed and predicted OA diurnal profiles for March 2006 shows that the model reproduces the gradual increase in OA concentrations during the day caused by both early morning primary emissions and the increase of SOA concentrations starting at sunrise. At the T0 site, both measurements and predictions suggest that organic mass has a high variation during the day. This is not the case at the $\mathrm{T} 1$ suburban site and especially at the T2 rural site. Most of the locally-produced organic mass at these sites is coming from the urban center and its concentration is depending more on the weather conditions than on the local emissions and photochemistry. Therefore, errors in the meteorological fields used by the model can lead to discrepancies between the predicted and the observed organic mass at these peripheral sites. The use of the same emission inventory for every weekday and time independent boundary conditions 
can also introduce errors on the predicted organic mass at the urban center and at areas close to the boundaries respectively. Despite that, the predicted chemical composition of $\mathrm{OA}$ is generally consistent with the PMF analysis results suggesting that the depiction in the model of the corresponding processes is not inconsistent with the observations.

Overall, $65 \%$ of the emitted POA is coming from mobile diesel sources with the rest coming from mobile gasoline $(15 \%)$, area $(10 \%)$, and point $(10 \%)$ sources, indicating that the modeled primary organic mass is dominated by mobile sources. Anthropogenic SOA is dominated by area and mobile gasoline sources. Aromatic VOC emissions consist of $48 \%$ vehicle exhaust (35\% gasoline and $13 \%$ diesel), $40 \%$ area, and $12 \%$ point emission sources. Nevertheless, PMCAMx-2008 predicts that the background concentration of OA is a significant fraction of the total OA in Mexico City center. In particular, only approximately half of the average OA consists of locally-emitted POA and locally-produced SOA, while the rest is coming mainly from the forest fires in the surrounding area either in the form of SOA or in the form of biomass burning OA. These results are also in agreement with the findings of Crounse et al. (2009) who estimated that biomass burning contributes $66 \%$ of the organic aerosol to the study area in March 2006. However, in this study the influence of biomass burning was only introduced by boundary conditions rather than by an explicitly treatment of biomass burning emissions. Given that these contributions are highly time-dependent on a day-by-day basis, this issue should be further investigated with more detail in future applications. Moreover, biogenic emissions also have a significant contribution to locally-produced total SOA (up to 70\%) and to total OA (up to $15 \%$ ). Even in the center of Mexico City, the predicted contribution of locally-produced biogenic SOA to locally-produced total SOA is approximately 20-30\%. The predictions of PMCAMx-2008 for biogenic SOA are lower than the results of Hodzic et al. (2009) who predicted that the relative contribution of biogenic SOA to total SOA in the city center is up to $40 \%$. This could be due to the lower predicted anthropogenic SOA concentrations in that modeling study.

The distribution of OA emissions to the low volatility bins appears to be important for the predicted POA as it has great impact to the initial partitioning between the aerosol and the gas phase. Increasing the aging reaction constant by one order of magnitude resulted in $20 \%$ higher OOA concentrations. Finally, including HONO emissions to the inventory used by the model, appear to be important for the production of OOA during the early morning hours, resulting in an increase of $25 \%$ during morning.

Acknowledgements. The authors thank Jihee Song for assistance with the MEGAN biogenic emissions estimates and Guohui Li for valuable comments. This research was supported by the European Union and the 7th Framework Programme under the project MEGAPOLI (Grant agreement no.: 212520) and NSF ATM 0732598. A. P. Tsimpidi, V. A. Karydis, and M. Zavala were supported by scholarships from the Molina Center for Energy and the Environment. L. T. Molina acknowledges support from NSF ATM 0528227 and ATM 0810931.

Edited by: U. Pöschl

\section{References}

Aiken, A. C. , Decarlo, P. F., Kroll, J. H., Worsnop, D. R., Huffman, J. A., Docherty, K. S., Ulbrich, I. M., Mohr, C., Kimmel, J. R., Sueper, D., Sun, Y., Zhang, Q., Trimborn, A., Northway, M., Ziemann, P. J., Canagaratna, M. R., Onasch, T. B., Alfarra, M. R., Prevot, A. S. H., Dommen, J., Duplissy, J., Metzger, A., Baltensperger, U., and Jimenez, J. L.: O/C and OM/OC Ratios of primary, secondary, and ambient organic aerosols with high resolution time-of-flight aerosol mass spectrometry, Environ. Sci. Technol., 42, 4478-4485, 2008.

Aiken, A. C., Salcedo, D., Cubison, M. J., Huffman, J. A., DeCarlo, P. F., Ulbrich, I. M., Docherty, K. S., Sueper, D., Kimmel, J. R., Worsnop, D. R., Trimborn, A., Northway, M., Stone, E. A., Schauer, J. J., Volkamer, R. M., Fortner, E., de Foy, B., Wang, J., Laskin, A., Shutthanandan, V., Zheng, J., Zhang, R., Gaffney, J., Marley, N. A., Paredes-Miranda, G., Arnott, W. P., Molina, L. T., Sosa, G., and Jimenez, J. L.: Mexico City aerosol analysis during MILAGRO using high resolution aerosol mass spectrometry at the urban supersite (T0) - Part 1: Fine particle composition and organic source apportionment, Atmos. Chem. Phys., 9, 66336653, doi:10.5194/acp-9-6633-2009, 2009.

Aiken, A. C., de Foy, B., Wiedinmyer, C., DeCarlo, P. F., Ulbrich, I. M., Wehrli, M. N., Szidat, S., Prevot, A. S. H., Noda, J., Wacker, L., Volkamer, R., Fortner, E., Wang, J., Laskin, A., Shutthanandan, V., Zheng, J., Zhang, R., Paredes-Miranda, G., Arnott, W. P., Molina, L. T., Sosa, G., Querol, X., and Jimenez, J. L.: Mexico city aerosol analysis during MILAGRO using high resolution aerosol mass spectrometry at the urban supersite (T0) - Part 2: Analysis of the biomass burning contribution and the non-fossil carbon fraction, Atmos. Chem. Phys., 10, 5315-5341, doi:10.5194/acp-10-5315-2010, 2010.

Aumont, B., Chervier, F., and Laval, S,: Contribution of HONO sources to the $\mathrm{NOx} / \mathrm{HOx} / \mathrm{O}_{3}$ chemistry in the polluted boundary layer, Atmos. Environ., 37, 487-498, 2003.

Bytnerowicz, A. and Fenn, M. E.: Nitrogen deposition in California forests: A review, Environ. Pol., 92, 127-146, 1996.

Carter, W. P. L.: Programs and Files Implementing the SAPRC99 Mechanism and its Associates Emissions Processing Procedures for Models-3 and Other Regional Models: http://pah.cert. ucr.edu/_carter/SAPRC99.htm, last access: 31 January 2000.

Crounse, J. D., DeCarlo, P. F., Blake, D. R., Emmons, L. K., Campos, T. L., Apel, E. C., Clarke, A. D., Weinheimer, A. J., McCabe, D. C., Yokelson, R. J., Jimenez, J. L., and Wennberg, P. O.: Biomass burning and urban air pollution over the Central Mexican Plateau, Atmos. Chem. Phys., 9, 4929-4944, doi:10.5194/acp-9-4929-2009, 2009.

DeCarlo, P. F., Dunlea, E. J., Kimmel, J. R., Aiken, A. C., Sueper, D., Crounse, J., Wennberg, P. O., Emmons, L., Shinozuka, Y., Clarke, A., Zhou, J., Tomlinson, J., Collins, D. R., Knapp, D., Weinheimer, A. J., Montzka, D. D., Campos, T., and Jimenez, J. L.: Fast airborne aerosol size and chemistry measurements above Mexico City and Central Mexico during the MILAGRO 
campaign, Atmos. Chem. Phys., 8, 4027-4048, doi:10.5194/acp8-4027-2008, 2008.

DeCarlo, P. F., Ulbrich, I. M., Crounse, J., de Foy, B., Dunlea, E. J., Aiken, A. C., Knapp, D., Weinheimer, A. J., Campos, T., Wennberg, P. O., and Jimenez, J. L.: Investigation of the sources and processing of organic aerosol over the Central Mexican Plateau from aircraft measurements during MILAGRO, Atmos. Chem. Phys., 10, 5257-5280, doi:10.5194/acp-10-52572010, 2010.

de Gouw, J. A., Middlebrook, A. M., Warneke, C., Goldan, P. D., Kuster, W. C., Roberts, J. M., Fehsenfeld, F. C., Worsnop, D. R., Canagaratna, M. R., Pszenny, A. A. P., Keene, W. C., Marchewka, M., Bertman, S. B., and Bates, T. S.: Budget of organic carbon in a polluted atmosphere: Results from the New England Air Quality Study in 2002, J. Geophys. Res., 110, D16305, doi:10.1029/2004JD004662, 2005.

de Gouw, J. A., Welsh-Bon, D., Warneke, C., Kuster, W. C., Alexander, L., Baker, A. K., Beyersdorf, A. J., Blake, D. R., Canagaratna, M., Celada, A. T., Huey, L. G., Junkermann, W., Onasch, T. B., Salcido, A., Sjostedt, S. J., Sullivan, A. P., Tanner, D. J., Vargas, O., Weber, R. J., Worsnop, D. R., Yu, X. Y., and Zaveri, R.: Emission and chemistry of organic carbon in the gas and aerosol phase at a sub-urban site near Mexico City in March 2006 during the MILAGRO study, Atmos. Chem. Phys., 9, 3425-3442, doi:10.5194/acp-9-3425-2009, 2009.

Dzepina, K., Volkamer, R. M., Madronich, S., Tulet, P., Ulbrich, I. M., Zhang, Q., Cappa, C. D., Ziemann, P. J., and Jimenez, J. L.: Evaluation of recently-proposed secondary organic aerosol models for a case study in Mexico City, Atmos. Chem. Phys., 9, 5681-5709, doi:10.5194/acp-9-5681-2009, 2009.

Doran, J. C., Barnard, J. C., Arnott, W. P., Cary, R., Coulter, R., Fast, J. D., Kassianov, E. I., Kleinman, L., Laulainen, N. S., Martin, T., Paredes-Miranda, G., Pekour, M. S., Shaw, W. J., Smith, D. F., Springston, S. R., and Yu, X.-Y.: The T1-T2 study: evolution of aerosol properties downwind of Mexico City, Atmos. Chem. Phys., 7, 1585-1598, doi:10.5194/acp-7-1585-2007, 2007.

Drewnick, F., Hings, S. S., DeCarlo, P., Jayne, J. T., Gonin, M., Fuhrer, K., Weimer, S., Jimenez, J. L., Demerjian, K. L., Borrmann, S., and Worsnop, D. R.: A new time-of-flight aerosol mass spectrometer (TOF-AMS) - Instrument description and first field deployment, Aerosol Sci. Technol., 39, 637-658, 10.1080/02786820500182040, 2005.

Farina, S. C., Adams, P. J., and Pandis, S. N.: Modeling global secondary organic aerosol formation and processing with the volatility basis set: Implications for anthropogenic secondary organic aerosol, J. Geophys. Res.-Atmos., 115, D09202, doi:10.1029/2009JD013046, 2010.

Fast, J., Aiken, A. C., Allan, J., Alexander, L., Campos, T., Canagaratna, M. R., Chapman, E., DeCarlo, P. F., de Foy, B., Gaffney, J., de Gouw, J., Doran, J. C., Emmons, L., Hodzic, A., Herndon, S. C., Huey, G., Jayne, J. T., Jimenez, J. L., Kleinman, L., Kuster, W., Marley, N., Russell, L., Ochoa, C., Onasch, T. B., Pekour, M., Song, C., Ulbrich, I. M., Warneke, C., WelshBon, D., Wiedinmyer, C., Worsnop, D. R., Yu, X.-Y., and Zaveri, R.: Evaluating simulated primary anthropogenic and biomass burning organic aerosols during MILAGRO: implications for assessing treatments of secondary organic aerosols, Atmos. Chem. Phys., 9, 6191-6215, doi:10.5194/acp-9-6191-2009, 2009.
Gaydos, T. M., Pinder, R. W., Koo, B., Fahey, K. M., and Pandis, S. N.: Development and application of a three-dimensional aerosol chemical transport model, PMCAMx, Atmos. Environ., 41, 2594-2611, 2007.

Heald, C. L., Jacob, D. J., Park, R. J., Russell, L. M., Huebert, B. J., Seinfeld, J. H., Liao, H., and Weber, R. J.: A large organic aerosol source in the free troposphere missing from current models, Geophys. Res. Lett, 32, L18809, doi:10.1029/2005GL023831, 2005.

Herndon, S. C., Onasch, T. B., Wood, E. C., Kroll, J. H., Canagaratna, M. R., Jayne, J. T., Zavala, M. A., Knighton, W. B., Mazzoleni, C., Dubey, M. K., Ulbrich, I. M., Jimenez, J. L., Seila, R., de Gouw, J. A., de Foy, B., Fast, J., Molina, L. T., Kolb, C. E., and Worsnop, D. R.: Correlation of secondary organic aerosol with odd oxygen in Mexico City, Geophys. Res. Lett., 35, L15804, doi:10.1029/2008GL034058, 2008.

Hildebrandt, L., Donahue, N. M., and Pandis, S. N.: High formation of secondary organic aerosol from the photo-oxidation of toluene, Atmos. Chem. Phys., 9, 2973-2986, doi:10.5194/acp-92973-2009, 2009.

Hodzic, A., Jimenez, J. L., Madronich, S., Aiken, A. C., Bessagnet, B., Curci, G., Fast, J., Lamarque, J.-F., Onasch, T. B., Roux, G., Schauer, J. J., Stone, E. A., and Ulbrich, I. M.: Modeling organic aerosols during MILAGRO: importance of biogenic secondary organic aerosols, Atmos. Chem. Phys., 9, 6949-6981, doi:10.5194/acp-9-6949-2009, 2009.

Hodzic, A., Jimenez, J. L., Madronich, S., Canagaratna, M. R., DeCarlo, P. F., Kleinman, L., and Fast, J.: Modeling organic aerosols in a megacity: potential contribution of semi-volatile and intermediate volatility primary organic compounds to secondary organic aerosol formation, Atmos. Chem. Phys., 10, 5491-5514, doi:10.5194/acp-10-5491-2010, 2010.

linuma, Y., Böge, O., Gnauk, T., and Hemnann, H.: Aerosol chamber study of the a-pinene/O3 reaction: Influence of particle acidity on aerosol yields and products, Atmos. Environ., 38, 761773, 2004.

Jang, M., Czoschke, N. M., Lee, S., and Kameris, R. M.: Heterogeneous atmospheric aerosol production by acid-catalyzed particle phase reactions, Nature, 298, 814-817, 2002.

Johnson, K. S., de Foy, B., Zuberi, B., Molina, L. T., Molina, M. J., Xie, Y., Laskin, A., and Shutthanandan, V.: Aerosol composition and source apportionment in the Mexico City Metropoli$\tan$ Area with PIXE/PESA/STIM and multivariate analysis, Atmos. Chem. Phys., 6, 4591-4600, doi:10.5194/acp-6-4591-2006, 2006.

Kalberer, M., Paulsen, D., Sax, M., Steinbacher., M., Dommen, J., Prevot, A. S. H., Fisseha, R., Weingartner, E., Frankevich, V., Zenobi, R., and Baltensperger U.: Identification of polymers as major components of atmospheric organic aerosols, Science, 303(5664), 1659-1662, 2004.

Karydis, V. A., Tsimpidi, A. P., and Pandis, S. N.: Evaluation of a three-dimensional chemical transport model (PMCAMx) in the eastern United States for all four seasons, J. Geoph. Res., 112, D14211, doi:10.1029/2006JD007890, 2007.

Karydis, V. A., Tsimpidi, A. P., Fountoukis, C., Nenes, A., Zavala, M., Molina, L. T., and Pandis, S. N.: Simulating the fine and coarse inorganic particulate matter concentrations in a polluted megacity, Atmos. Environ., 44, 608-620, 2010.

Kleinman, L. I., Springston, S. R., Daum, P. H., Lee, Y.-N., Nun- 
nermacker, L. J., Senum, G. I., Wang, J., Weinstein-Lloyd, J., Alexander, M. L., Hubbe, J., Ortega, J., Canagaratna, M. R., and Jayne, J.: The time evolution of aerosol composition over the Mexico City plateau, Atmos. Chem. Phys., 8, 1559-1575, doi:10.5194/acp-8-1559-2008, 2008.

Kostenidou, E., Pathak, R. K., and Pandis, S. N.: An algorithm for the calculation of secondary organic aerosol density combining AMS and SMPS data, Aerosol Sci. Technol., 41, 1002-1010, doi:10.1080/02786820701666270, 2007.

Lane, T. E., Donahue, N. M., and Pandis, S. N.: Simulating secondary organic aerosol formation using the Volatility Basis-Set approach in a chemical transport model, Atmos. Environ., 42, 7439-7451, 2008a.

Lane, T. E., Donahue, N. M., and Pandis, S. N.: Effect of NOx on secondary organic aerosol concentrations, Environ. Sci. Technol., 42, 6022-6027, 2008b.

Lanz, V. A., Alfarra, M. R., Baltensperger, U., Buchmann, B., Hueglin, C., and Prvt, A. S. H.: Source apportionment of submicron organic aerosols at an urban site by factor analytical modelling of aerosol mass spectra, Atmos. Chem. Phys., 7, 15031522, doi:10.5194/acp-7-1503-2007, 2007.

Li, G., Lei, W., Zavala, M., Volkamer, R., Dusanter, S., Stevens, P., and Molina, L. T.: Impacts of HONO sources on the photochemistry in Mexico City during the MCMA-2006/MILAGO Campaign, Atmos. Chem. Phys., 10, 6551-6567, doi:10.5194/acp10-6551-2010, 2010.

Li, G., Zavala, M., Lei, W., Tsimpidi, A. P., Karydis, V. A., Pandis, S. N., Canagaratna, M. R., and Molina, L. T.: Simulations of organic aerosol concentrations in Mexico City using the WRFCHEM model during the MCMA-2006/MILAGRO campaign, Atmos. Chem. Phys., 11, 3789-3809, doi:10.5194/acp-11-37892011, 2011.

Lim, H. J, Carlton, A. C., and Turpin, B. J.: Isoprene forms secondary organic aerosol through cloud processing: model simulations, Environ. Sci. Technol., 39, 4441-4446, 2005.

Liu, Y., El Haddad, I., Scarfogliero, M., Nieto-Gligorovski, L., Temime-Roussel, B., Quivet, E., Marchand, N., PicquetVarrault, B., and Monod, A.: In-cloud processes of methacrolein under simulated conditions - Part 1: Aqueous phase photooxidation, Atmos. Chem. Phys., 9, 5093-5105, doi:10.5194/acp-95093-2009, 2009.

Mohr, C., Huffman, J. A., Cubison, M. J., Aiken, A. C., Docherty, K. S., Kimmel, J. R., Ulbrich, I. M., Hannigan, M., and Jimenez, J. L.: Characterization of primary organic aerosol emissions from meat cooking, trash burning, and motor vehicles with HighResolution Aerosol Mass Spectrometry and comparison with ambient and chamber observations, Environ. Sci. Technol., 43, 2443-2449, doi:10.1021/es8011518, 2009.

Molina, L. T. and Molina, M. J.: Air Quality in the Mexico Megacity: An Integrated Assessment, Kluwer Academic Publishers: Dordrecht, The Netherlands, 384 pp., 2002.

Molina, L. T., Kolb, C. E., de Foy, B., Lamb, B. K., Brune, W. H., Jimenez, J. L., Ramos-Villegas, R., Sarmiento, J., ParamoFigueroa, V. H., Cardenas, B., Gutierrez-Avedoy, V., and Molina, M. J.: Air quality in North America's most populous city overview of the MCMA-2003 campaign, Atmos. Chem. Phys., 7, 2447-2473, doi:10.5194/acp-7-2447-2007, 2007.

Molina, L. T., Madronich, S., Gaffney, J. S., Apel, E., de Foy, B., Fast, J., Ferrare, R., Herndon, S., Jimenez, J. L., Lamb, B.,
Osornio-Vargas, A. R., Russell, P., Schauer, J. J., Stevens, P. S., Volkamer, R., and Zavala, M.: An overview of the MILAGRO 2006 Campaign: Mexico City emissions and their transport and transformation, Atmos. Chem. Phys., 10, 8697-8760, doi:10.5194/acp-10-8697-2010, 2010.

Murphy, B. N. and Pandis, S. N.: Simulating the formation of semivolatile primary and secondary organic aerosol in a regional Chemical Transport Model, Environ. Sci. Technol., 43, 47224728, doi:10.1021/es803168a, 2009.

Ng, N. L., Kroll, J. H., Keywood, M. D., Bahreini, R., Varutbangkul, V., Flagan, R. C., Seinfeld, J. H., Lee, A., and Goldstein, A. H.: Contribution of first- versus second-generation products to secondary organic aerosols formed in the oxidation of biogenic hydrocarbons, Environ. Sci. Technol., 40, 2283-2297, doi:10.1021/es052269u, 2006.

Ng, N. L., Kwan, A. J., Surratt, J. D., Chan, A. W. H., Chhabra, P. S., Sorooshian, A., Pye, H. O. T., Crounse, J. D., Wennberg, P. O., Flagan, R. C., and Seinfeld, J. H.: Secondary organic aerosol (SOA) formation from reaction of isoprene with nitrate radicals $\left(\mathrm{NO}_{3}\right)$, Atmos. Chem. Phys., 8, 4117-4140, doi:10.5194/acp-84117-2008, 2008.

Paatero, P. and Tapper, U.: Positive matrix factorization - a nonnegative factor model with optimal utilization of error-estimates of data values, Environmetrics, 5, 111-126, 1994

Pope, C. A., Burnett, R. T., Thun, M. J., Calle, E. E., Krewski, D., Ito, K., and Thurston, G. D.: Lung cancer, cardiopulmonary mortality, and long-term exposure to fine particulate air pollution, J. Am. Med. Assoc., 287, 1132-1141, 2002.

Querol, X., Pey, J., Minguillón, M. C., Pérez, N., Alastuey, A., Viana, M., Moreno, T., Bernabé, R. M., Blanco, S., Cárdenas, B., Vega, E., Sosa, G., Escalona, S., Ruiz, H., and Artíñano, B.: PM speciation and sources in Mexico during the MILAGRO-2006 Campaign, Atmos. Chem. Phys., 8, 111-128, doi:10.5194/acp8-111-2008, 2008.

Racherla, P. N. and Adams, P. J.: Sensitivity of global tropospheric ozone and fine particulate matter concentrations to climate change, J. Geophys. Res., 111, D24103, doi:10.1029/2005JD006939, 2006.

Robinson, A. L., Donahue, N. M., Shrivastava, M. K., Weitkamp, E. A., Sage, A. M., Grieshop, A. P., Lane, T. E., Pandis, S. N., and Pierce, J. R.: Rethinking organic aerosols: semivolatile emissions and photochemical aging, Science, 315, 1259-1262, 2007.

Shrivastava, M. K., Lane, T. E., Donahue, N. M., Pandis, S. N., and Robinson, A. L.: Effects of gas-particle partitioning and aging of primary emissions on urban and regional organic aerosol concentrations, J. Geophys. Res., 113, D18301, doi:10.1029/2007JD009735, 2008.

Shrivastava, M., Fast, J., Easter, R., Gustafson Jr., W. I., Zaveri, R. A., Jimenez, J. L., Saide, P., and Hodzic, A.: Modeling organic aerosols in a megacity: comparison of simple and complex representations of the volatility basis set approach, Atmos. Chem. Phys. Discuss., 10, 30205-30277, doi:10.5194/acpd-10-302052010, 2010.

Song, J., Lei, W., Bei, N., Zavala, M., de Foy, B., Volkamer, R., Cardenas, B., Zheng, J., Zhang, R., and Molina, L. T.: Ozone response to emission changes: a modeling study during the MCMA-2006/MILAGRO Campaign, Atmos. Chem. Phys., 10, 3827-3846, doi:10.5194/acp-10-3827-2010, 2010.

Stone, E. A., Snyder, D. C., Sheesley, R. J., Sullivan, A. P., We- 
ber, R. J., and Schauer, J. J.: Source apportionment of fine organic aerosol in Mexico City during the MILAGRO experiment 2006, Atmos. Chem. Phys., 8, 1249-1259, doi:10.5194/acp-81249-2008, 2008.

Stone, E. A., Hedman, C. J., Zhou, J., Mieritz, A., and Schauer, J. J: Insights into the nature of secondary organic aerosol in Mexico City during the MILAGRO experiment 2006, Atmos. Environ., 44, 312-319, 2010.

Tsimpidi, A. P., Karydis, V. A., Zavala, M., Lei, W., Molina, L., Ulbrich, I. M., Jimenez, J. L., and Pandis, S. N.: Evaluation of the volatility basis-set approach for the simulation of organic aerosol formation in the Mexico City metropolitan area, Atmos. Chem. Phys., 10, 525-546, doi:10.5194/acp-10-525-2010, 2010.

Ulbrich, I. M., Canagaratna, M. R., Zhang, Q., Worsnop, D. R., and Jimenez, J. L.: Interpretation of organic components from Positive Matrix Factorization of aerosol mass spectrometric data, Atmos. Chem. Phys., 9, 2891-2918, doi:10.5194/acp-9-2891-2009, 2009.

Volkamer, R., Jimenez, J. L., San Martini, F., Dzepina, K., Zhang, Q., Salcedo, D., Molina, L. T., Worsnop, D. R., and Molina, M. J.: Secondary organic aerosol formation from anthropogenic air pollution: Rapid and higher than expected, Geophys. Res. Lett., 33, L17811, doi:10.1029/2006GL026899, 2006.

Volkamer, R., Martini, F. S., Molina, L. T., Salcedo, D., Jimenez, J. L., and Molina, M. J.: A missing sink for gas-phase glyoxal in Mexico City: formation of secondary organic aerosol, Geophys. Res. Lett., 34, L19807, doi:10.1029/2007GL030752, 2007.

Wameck, P.: In-cloud chemistry opens pathway to the formation of oxalic acid in the marine atmospbere, Atmos. Environ., 37, 2423-2427, 2003.

Watson, J. G.: Visibility: Science and regulation, J. Air Waste Manage., 52, 628-713, 2002.

Whrnschimmel, H., Magaña, M., Stahel, W. A., Blanco, S., Acuña, S., Prez, J. M., González, S., Gutiérrez, V., Wakamatsu, S., and Cárdenas, B.: Measurements and receptor modeling of volatile organic compounds in Southeastern Mexico City, 2000-2007, Atmos. Chem. Phys., 10, 9027-9037, doi:10.5194/acp-10-90272010, 2010.
Wood, E. C., Canagaratna, M. R., Herndon, S. C., Onasch, T. B., Kolb, C. E., Worsnop, D. R., Kroll, J. H., Knighton, W. B., Seila, R., Zavala, M., Molina, L. T., DeCarlo, P. F., Jimenez, J. L., Weinheimer, A. J., Knapp, D. J., Jobson, B. T., Stutz, J., Kuster, W. C., and Williams, E. J.: Investigation of the correlation between odd oxygen and secondary organic aerosol in Mexico City and Houston, Atmos. Chem. Phys., 10, 8947-8968, doi:10.5194/acp-10-8947-2010, 2010.

Yokelson, R. J., Urbanski, S. P., Atlas, E. L., Toohey, D. W., Alvarado, E. C., Crounse, J. D., Wennberg, P. O., Fisher, M. E., Wold, C. E., Campos, T. L., Adachi, K., Buseck, P. R., and Hao, W. M.: Emissions from forest fires near Mexico City, Atmos. Chem. Phys., 7, 5569-5584, doi:10.5194/acp-7-5569-2007, 2007.

Yu, X.-Y., Cary, R. A., and Laulainen, N. S.: Primary and secondary organic carbon downwind of Mexico City, Atmos. Chem. Phys., 9, 6793-6814, doi:10.5194/acp-9-6793-2009, 2009.

Zhang, Q., Jimenez, J. L., Canagaratna, M. R., Allan, J. D., Coe, H., Ulbrich, I., Alfarra, M. R., Takami, A., Middlebrook, A. M., Sun, Y. L., Dzepina, K., Dunlea, E., Docherty, K., DeCarlo, P. F., Salcedo, D., Onasch, T., Jayne, J. T., Miyoshi, T., Shimono, A., Hatakeyama, S., Takegawa, N., Kondo, Y., Schneider, J., Drewnick, F., Borrmann, S., Weimer, S., Demerjian, K., Williams, P., Bower, K., Bahreini, R., Cottrell, L., Griffin, R. J., Rautiainen, J., Sun, J. Y., Zhang, Y. M., and Worsnop, D. R.: Ubiquity and dominance of oxygenated species in organic aerosols in anthropogenically-influenced Northern Hemisphere midlatitudes, Geophys. Res. Lett., 34, L13801, doi:10.1029/2007GL029979, 2007. 